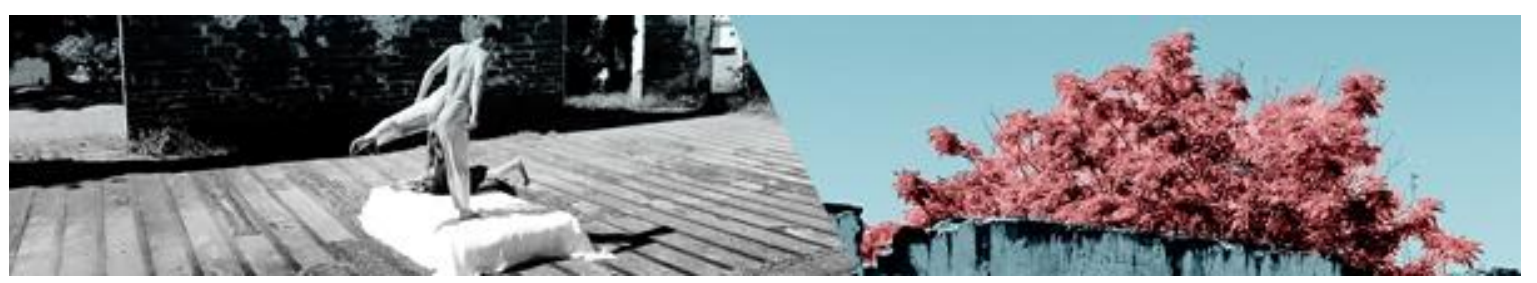

\title{
PRINCÍPIOS ORGANIZATIVOS DE MOVIMENTO NAS AULAS DE DANÇA CONTEMPORÂNEA DE EVA SCHUL
}

Fellipe Santos Resende ${ }^{1}$ Suzane Weber da Silva²

\begin{abstract}
Resumo: Este artigo busca apresentar alguns dos princípios organizativos de movimento que estruturam as aulas de dança contemporânea de Eva Schul. A presença regular dos autores como bailarinos-observadores no ambiente da sala de aula foi muito importante para a construção e identificação dos materiais da pesquisa. A abordagem metodológica contou com diário de campo, registros foto e videográficos e entrevista semiestruturada. As estratégias de descrição e contextualização imagética foram usadas para delinear e dar corpo aos princípios, dentre os quais destacamos dois neste artigo: o estudo do peso e do esforço mínimo, e o estudo do fluxo e da qualidade de fluência.
\end{abstract}

Palavras-chave: Dança contemporânea; Princípios organizativos; Eva Schul.

\section{ORGANIZATIONAL PRINCIPLES OF MOVEMENT IN THE CONTEMPORARY DANCE CLASSES OF EVA SCHUL}

\begin{abstract}
This article aims to present some of the organizational principles of movement that structure Eva Schul's contemporary dance classes. The regular presence of the authors as dancers-observers in the classroom environment was very important for the construction and identification of the research materials. The methodological approach included a field diary, photo and videographic records, and semi-structured interview. The strategies of description and imagetic contextualisation were used to outline and give substance to the principles, among which we highlight two in this article: the study of weight and of minimum effort, and the study of flow and the quality of fluency.
\end{abstract}

Keywords: Contemporary dance; Organizational principles; Eva Schul.

\section{Introdução}

Propomos neste artigo, a partir do contato aprofundado com a técnica ${ }^{3}$ de dança contemporânea elaborada pela mestra e coreógrafa Eva Schul ${ }^{4}$, relatar

\footnotetext{
${ }^{1}$ Fellipe Santos Resende - Doutorando e Mestre pelo Programa de Pós-Graduação em Artes Cênicas da Universidade Federal do Rio Grande do Sul (UFRGS). Especialista em Dança, Licenciando em Dança (UFRGS). Bacharel em Fisioterapia pela Universidade Federal de Goiás (UFG).

2 Suzane Weber da Silva - Professora no Programa de Pós-Graduação em Artes Cênicas e professora associada no Departamento de Arte Dramática (UFRGS). Doutora em Estudos e Práticas Artísticas pela Université du Québec à Montréal (Canadá), Mestre em Ciências do Movimento Humano e Bacharel em Interpretação Teatral (UFRGS).

${ }^{3}$ Embora se saiba que muitas aulas de dança geralmente se apoiam em mais de uma técnica corporal, será usada neste artigo a nomenclatura 'técnica', visto que mesmo estando no singular compreende um fazer e ensinar plurais.

${ }^{4}$ Nascida num campo de refugiados para judeus na Itália em 1948, Eva Schul se estabelece com sua família no Brasil em 1956, entrando no Rio Grande do Sul pelo Uruguai. Apátrida até os 18 anos,
}

RESENDE, Fellipe Santos; SILVA, Suzane Weber da. Princípios organizativos de movimento nas aulas de dança contemporânea de Eva Schul. Revista da FUNDARTE, Montenegro, p.317-338, ano 19, no 37, Janeiro/Março.

Disponível em: http://.seer.fundarte.rs.gov.br/index.php/RevistadaFundarte/index> 30 de março de 2019. 


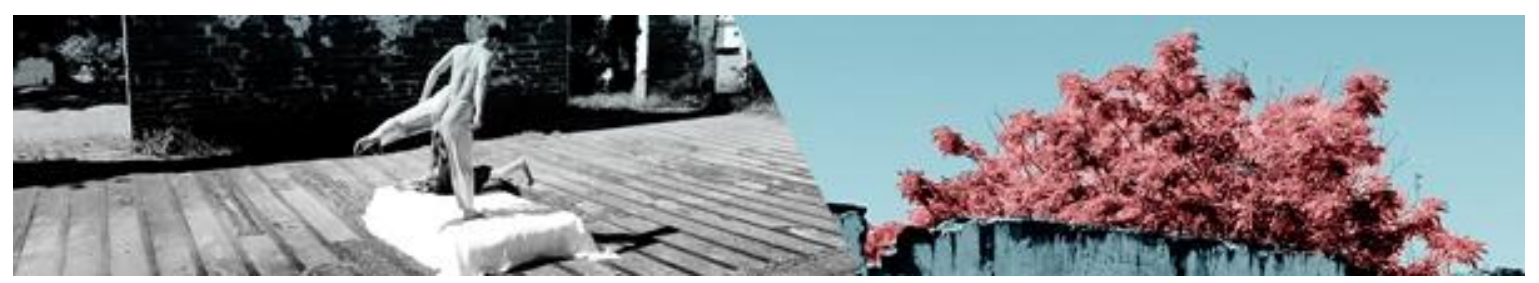

alguns dos princípios que norteiam e organizam seu fazer dança, contextualizando exemplos de movimentos dançados singulares à sua condução e pedagogia.

O contato continuado com a técnica em questão é um importante fator de justificativa deste estudo, tendo em vista que consideramos o espaço da sala de aula como fonte significativa de materiais de corpo e subsídios sensoriais e motores, um ambiente de estudo e aplicações práticas que deflagram construções e desconstruções da técnica em dança, com o corpo experimentando e se apropriando de proposições através do movimento.

Uma forte intenção de compreender as diretrizes de organização dessas aulas se tornou mais latente com o fato de que Eva Schul tem atuado nessa expertise e campo do saber há quase cinco décadas ${ }^{5}$, tendo formado gerações de bailarinos e atuado de forma consistente no cenário artístico regional, nacional e internacional. Dessa forma o propósito de compreender princípios organizativos de movimento que estruturam suas aulas de dança, e apresentar aqui alguns deles, é nosso objetivo nesse artigo.

Circunscritos diretamente na prática do tema estudado, nos situamos na dupla perspectiva de bailarinos-observadores, ora fazendo as aulas e assumindo a experimentação direta das proposições dançadas dentro da referida técnica, ora priorizando registros de ordem descritiva, imagética e cinestésica. Nesse sentido, ambos os estados de corpo assumidos na prática regular das aulas - olhar mais "interno" - e no acompanhamento mais indireto dos movimentos e sequências observação mais "externa" - configuram nosso plano de fundo perceptivo na apreensão e construção dos materiais e dados da pesquisa.

Quanto à atribuição de pesquisador-participante assumida, recorremos a Dantas (2007), quando a mesma teoriza sobre a presença dos pesquisadores no terreno da pesquisa, estando estes implicados em observar diretamente

optou pela cidadania brasileira ao atingir a maioridade (DANTAS, 2013). É uma referência nacional no campo da dança, tendo em sua formação influências do ballet, dança moderna e pós-moderna, em nível internacional. É fundadora e diretora da Ânima Cia. de Dança (1991), atuando na Região Sul, e fortemente em Porto Alegre nas últimas três décadas.

${ }^{5}$ Eva Schul iniciou sua vida docente aos 13 anos, passando por diversas experiências pedagógicas em Arte. Embora seu currículo neste campo não tenha uma linearidade cronológica ininterrupta, Eva considera ter aproximadamente 48 anos de carreira como professora de dança.

RESENDE, Fellipe Santos; SILVA, Suzane Weber da. Princípios organizativos de movimento nas aulas de dança contemporânea de Eva Schul. Revista da FUNDARTE, Montenegro, p.317-338, ano 19, nำ 37, Janeiro/Março.

Disponível em: http://.seer.fundarte.rs.gov.br/index.php/RevistadaFundarte/index> 30 de março de 2019. 


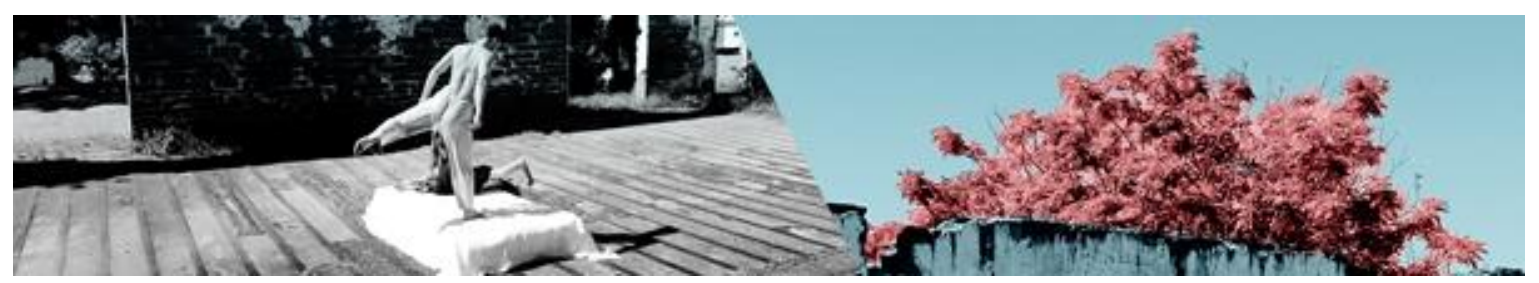

comportamentos e situações vividas pelos indivíduos num determinado contexto: neste caso as aulas de Eva Schul, um contexto observado e incorporado.

Baseamos nosso estudo qualitativo do movimento dançado (categorizado como sistema de uso único6) nas estratégias de descrição e contextualização imagética. O feedback descritivo versa de maneira diluída com anotações do diário de campo, materiais da entrevista com Eva Schul, observações e impressões perceptivas a partir da prática regular das aulas. A contextualização através de imagens, por sua vez, além de considerar os registros foto e videográficos, se articula com as visualidades e comandos sugeridos em aula por Eva.

\section{Situando a pesquisa em torno dos princípios organizativos}

Os processos referentes ao fazer e ensinar dança de Eva Schul não ficaram estanques ou indiferentes ao avanço de conhecimentos sobre o corpo dançante. Mediante sua formação continuada ${ }^{7}$ Eva Schul aperfeiçoou suas diretrizes dancísticas, estruturando diferentes formatos de aulas, cada vez mais cheias de traços próprios. Algumas dessas aulas enfatizam a formação técnica do corpo a partir da prática frequente de um acervo estruturado, porém flexível, de movimentos, enquanto outras têm maior foco na improvisação, dinâmicas de jogo e outros procedimentos compositivos.

Ao descrevermos nosso recorte em torno das chamadas 'aulas de técnica'8, direcionamos o olhar para exercícios e sequências coreografadas, que, através da prática e estudo continuados, estimulam a incorporação de qualidades de movimento específicas do repertório de Eva.

\footnotetext{
${ }^{6}$ Conforme a categorização proposta por Brennan (1999) este estudo é um sistema de uso único. Nessa designação o pesquisador estrutura um método particular de classificação e análise do movimento para fins de ajustar o formato do procedimento à questão da pesquisa, sendo geralmente usado pelo pesquisador que o concebeu.

7 Tal formação inclui grandes temporadas de estudo em Nova York (DANTAS, 2013), tanto com Alwin Nikolais (1910-1993), quanto com Hanya Holm (1893-1992), de quem Nikolais foi discípulo: ambos coreógrafos e importantes mestres da dança moderna norte-americana. Demais influências são oriundas de vivências em outras técnicas de dança moderna, improvisação e composição, ideias e conceitos da dança pós-moderna, além de princípios de análise do movimento com a fisioterapeuta e bailarina Irmgard Bartenieff (1900-1981), discípula e colaboradora de Rudolf Laban (1879-1958).

${ }^{8}$ Essa nomenclatura conferida por Eva Schul não implica a ausência de diretrizes técnicas nos outros formatos de aula, como as de improvisação e composição, por exemplo.
}

RESENDE, Fellipe Santos; SILVA, Suzane Weber da. Princípios organizativos de movimento nas aulas de dança contemporânea de Eva Schul. Revista da FUNDARTE, Montenegro, p.317-338, ano 19, no 37, Janeiro/Março.

Disponível em: http://.seer.fundarte.rs.gov.br/index.php/RevistadaFundarte/index> 30 de março de 2019. 


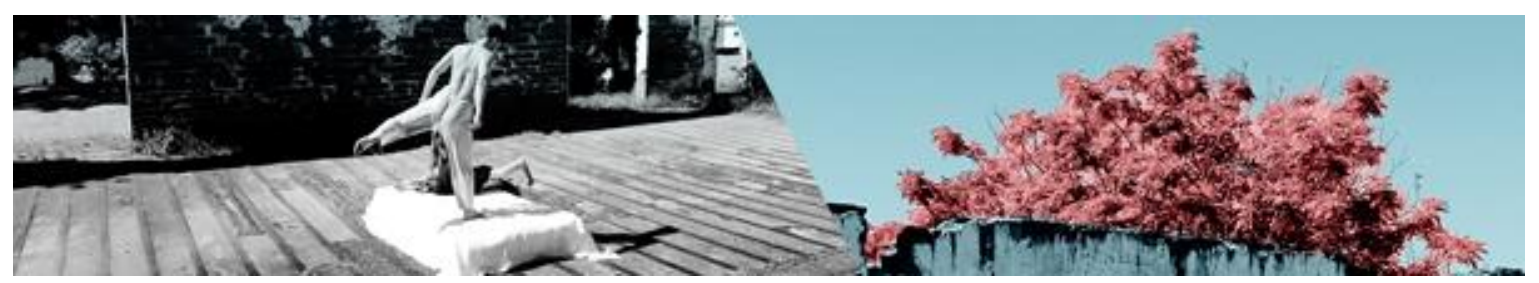

Os princípios organizativos aqui analisados contemplam traços abordados em aulas de períodos distintos, comuns a exercícios e sequências propostos em diferentes pontos cronológicos. Eles conjugam raciocínios importantes que se mantiveram e ganharam destaque na pedagogia de Eva Schul, independente do nível de dificuldade da aula: iniciante, intermediário ou avançado.

Quanto à expressão princípios organizativos, situamos que é referida na literatura como um grupo de parâmetros e recursos identificáveis numa composição em dança feitos sem o auxílio de conjuntos programáticos estruturados previamente com rigor (LESTE, 2013). Nessa pesquisa, no entanto, o termo princípios organizativos não tem ligação direta com estratégias compositivas, pois busca por norteamentos, diretrizes e qualidades do mover-se que estruturam e dão eixo às aulas de dança contemporânea de Eva Schul.

Embora estejam identificados separadamente para fins de análise, os princípios são intimamente relacionados e se dialogam constantemente, podendo ser mais presentes em um ou outro segmento das aulas. Nelas geralmente se contemplam um significativo trabalho de chão, aquecimento e soltura articular, o estudo de formas e vetores na coluna vertebral, membros superiores e inferiores (pernas e braços), o fortalecimento de musculatura central e profunda do corpo, e o estudo do espaço, linhas e vetores, dentre outros. Há conduções verbais, táteis e visuais dadas por Eva para que se atinja um estado de corpo consciente, e uma progressiva mobilização e engajamento das partes do corpo. A aula avança na complexidade das posturas e nos níveis de altura, valorizando principalmente uma gestão inteligente dos esforços e uma condução fluida dos movimentos.

Os princípios organizativos são designados junto da palavra estudo à medida que correspondem a um trabalho que se instrumentaliza e se aperfeiçoa pela continuidade, repetição consciente e progressão de cada um nas aulas de dança. Por serem estudados, são acessados e revisitados com expressiva frequência, sendo apropriados na/pela carne, mediante a disponibilidade assumida e a evolução alcançada por cada corpo-sujeito, havendo, portanto, formas singulares de incorporação dos mesmos. Nesse artigo apresentamos dois dos princípios

RESENDE, Fellipe Santos; SILVA, Suzane Weber da. Princípios organizativos de movimento nas aulas de dança contemporânea de Eva Schul. Revista da FUNDARTE, Montenegro, p.317-338, ano 19, no 37, Janeiro/Março.

Disponível em: http://.seer.fundarte.rs.gov.br/index.php/RevistadaFundarte/index> 30 de março de 2019. 


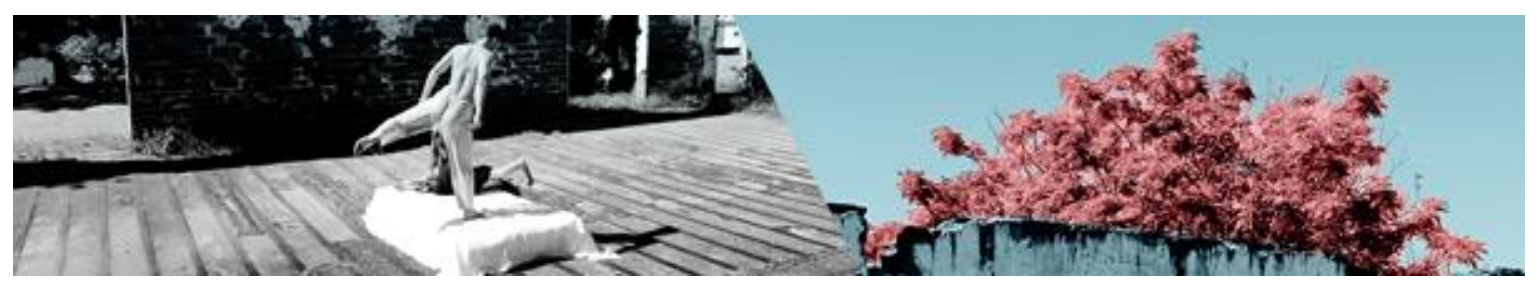

identificados na técnica de Eva Schul: o estudo do peso e do esforço mínimo, e o estudo do fluxo e da qualidade de fluência.

\section{Estudo do peso e do esforço mínimo}

De maneira geral o fator peso refere-se a mudanças na força usada pelo corpo ao mover-se, sendo mobilizado para empurrar, puxar ou carregar objetos, tocar em outro corpo, entre outros, relacionando-se com "o quê" do movimento, com a sensação ou a intenção ao realizá-lo (FERNANDES, 2006). Do ponto de vista mais físico o peso é uma força advinda da gravidade, sofrida por um objeto ou alguém. Como não está isolado, comporta outros elementos em diferentes graus de consciência, tais como nossas memórias: "massas" emocionais, cognitivas, instrumentais, sensório-motoras, socioculturais, etc. No campo da dança, a compreensão do peso é algo que foi bastante valorizado na dança moderna, sendo Rudolf Laban $^{9}$ um dos precursores na busca por decifrar esse fator de movimento e pensá-lo em relação com a memória corporal. Segundo Annie Suquet (2008):

A grande intuição de Laban [...] consiste, em ter articulado a questão da memória corporal com a da relação às leis da gravidade. Com efeito, como o bailarino transporta seu corpo - a dança, não é, na sua definição elementar, a transferência do peso do corpo no tempo e no espaço? (SUQUET, 2008. p. 258).

Nosso peso se modula, intensifica ou rarefaz. Abandona-se e se recupera. Inaugura-se na percepção gravitária ${ }^{10}$. Posta-se, projeta-se e retrai, comporta a presença cênica, a atenção em aula. Dobra, estende, afasta, aproxima, é lançado e recolhido. Ele é. Somos nosso peso. Nosso peso nos é.

A partir deste fator de movimento muito importante nas aulas de Eva Schul apontamos o princípio do estudo do peso e do esforço mínimo. Alguns dos

\footnotetext{
${ }^{9}$ Rudolf Laban: coreógrafo, bailarino e pedagogo do movimento; criador de um importante método para análise e notação do movimento que considera os fatores de movimento tempo, peso, espaço e fluxo (FERNANDES, 2006).

${ }^{10}$ A gravidade é um fator constante agindo no movimento humano, visto que mantemos posições a favor ou contra suas ações (FITT, 1996). Seu efeito em qualquer massa (inanimada ou não) é empurrá-la para baixo, na direção do solo em uma linha vertical.
}

RESENDE, Fellipe Santos; SILVA, Suzane Weber da. Princípios organizativos de movimento nas aulas de dança contemporânea de Eva Schul. Revista da FUNDARTE, Montenegro, p.317-338, ano 19, n 37, Janeiro/Março.

Disponível em: http://.seer.fundarte.rs.gov.br/index.php/RevistadaFundarte/index> 30 de março de 2019. 


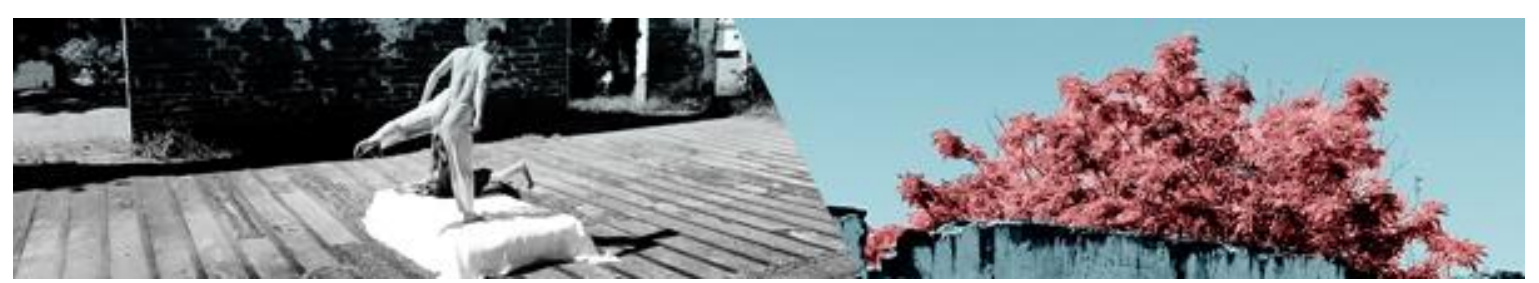

movimentos e elementos que o enfatizam incluem: alavanca, pêndulo (swing), momentum, lançamento e abandono do segmento, e deslocamento em torção no nível baixo.

Na Física a alavanca é uma barra rígida que pode girar em torno de um ponto de apoio, com potencial para multiplicar a força em outro objeto. No corpo em movimento, um braço ou uma perna podem agir, por exemplo, como uma alavanca comprida (quando estão projetados ou estendidos para fora/longe do centro do corpo) ou curta (quando estão dobrados ou de alguma forma mais próximos do centro do corpo). Em suas aulas, Eva Schul comenta, com frequência, o quanto foi necessário recorrer aos livros de física para compreender certos elementos nas aulas de dança moderna de sua mestra Hanya Holm: uma grande referência no estudo de queda e recuperação do peso do corpo na dança e uma das precursoras da dança moderna com a qual Eva teve a oportunidade de estudar em uma de suas imersões nos EUA.

Como um primeiro exemplo para compreender o uso da alavanca na técnica de Eva Schul podemos pensar num tipo específico de pirueta ou giro onde um membro inferior do bailarino, a perna direita, por exemplo, como alavanca, é lançada estendida no espaço, longe do centro, tendo em contrapartida a perna esquerda, a pelve e o tronco como eixo (quadro esquerdo - figura 1). Somado a esse movimento, podemos adicionar uma breve flexão do joelho da perna direita que antes foi lançada estendida, fazendo a alavanca deste membro se encurtar e o corpo acelerar durante o movimento rotativo.

RESENDE, Fellipe Santos; SILVA, Suzane Weber da. Princípios organizativos de movimento nas aulas de dança contemporânea de Eva Schul. Revista da FUNDARTE, Montenegro, p.317-338, ano 19, no 37, Janeiro/Março.

Disponível em: http://.seer.fundarte.rs.gov.br/index.php/RevistadaFundarte/index> 30 de março de 2019. 

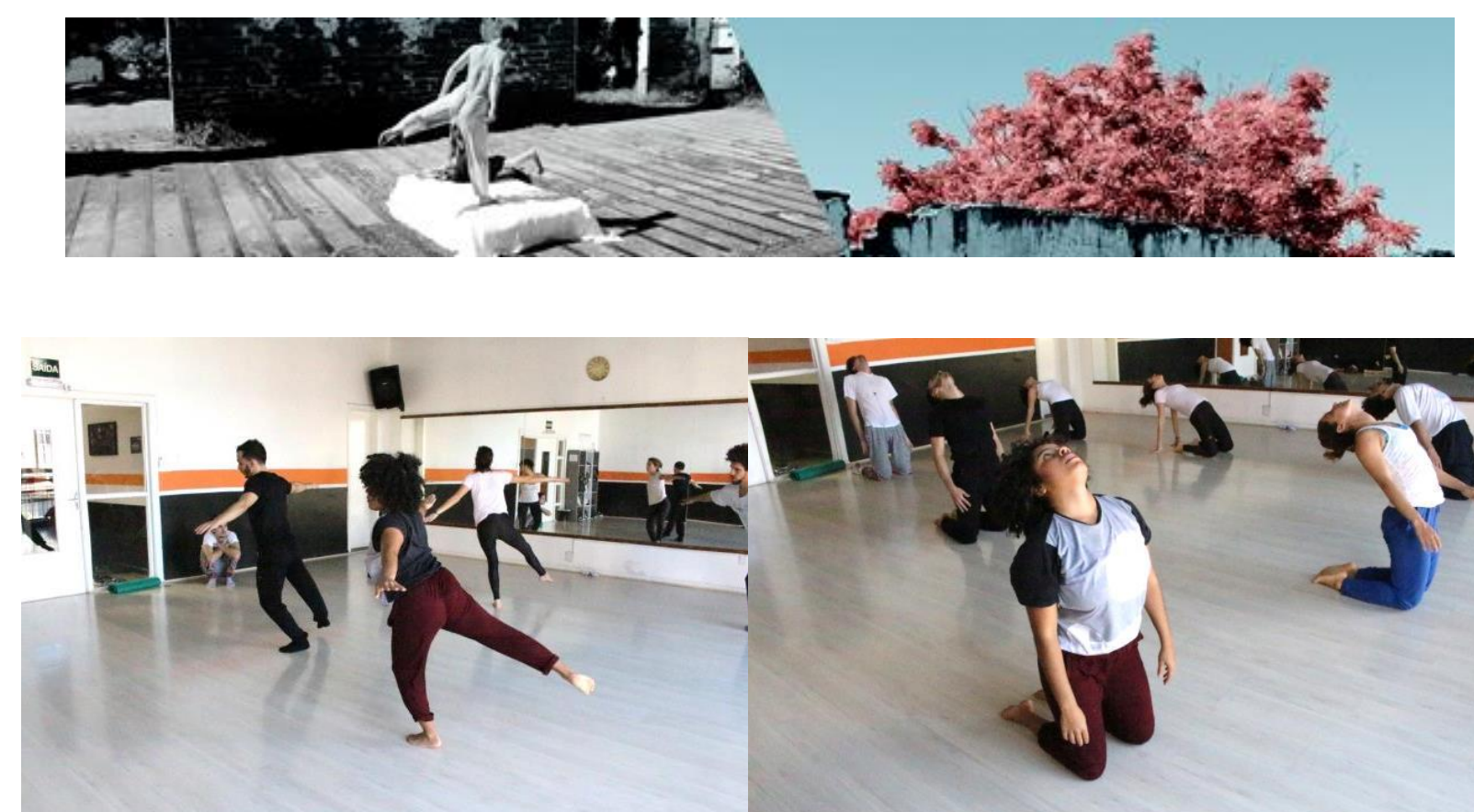

Figura 1. Registros fotográficos de exercícios que exploram alavancas corporais. À esquerda um movimento em que a perna direita em extensão é projetada no espaço num movimento giratório, formando uma alavanca comprida bem periférica que faz o corpo seguir uma trajetória circular de giro com mais definição. À direita, um exemplo em que os bailarinos usam toda a superfície das pernas e a força anterior das coxas para projetarem o peso do corpo para frente, tendo este iniciado arqueado para trás numa extensão de tronco e pesçoco.

Fonte: Acervo fotográfico da pesquisa.

A sensação para quem executa a ação de lançar a perna no giro aproxima-se de uma percepção do pé como uma bola/ponto periférico, orbitando em torno do corpo ou agindo como a extremidade de um transferidor, desenhando a trajetória do membro lançado no espaço. O uso dos braços abertos pode aparecer ainda como as asas de um planador, numa forma de impulsionar e/ou estabilizar o giro. O que importa nesse exemplo é a noção de alavanca como uma ferramenta aplicável na técnica. Cabe ao bailarino modular o movimento, controlando seu impulso para mais ou para menos, ou deixando que as tensões produzidas se esvaiam para o espaço e a energia usada no giro reverbere até o fim.

De acordo com Eva essa estratégia ensina que as partes do corpo podem ser usadas como alavanca para se projetar no espaço, acelerando ou desacelerando; e que um segmento corporal pode ser usado para alavancar outro, numa direção e intenção específicas (quadro direito - figura 1). Assim, ela instiga o bailarino a usar os recursos que possui (altura, nível de flexibilidade, ou comprimento e peso dos membros, por exemplo) para se deslocar e atingir a qualidade de um movimento em questão.

Outro exemplo contemplado neste princípio é o pêndulo, um termo que faz referência à trajetória curva e oscilatória de um segmento do corpo lançado no espaço em torno de um eixo estável, ou ponto fixo. No desenho espacial traçado,

RESENDE, Fellipe Santos; SILVA, Suzane Weber da. Princípios organizativos de movimento nas aulas de dança contemporânea de Eva Schul. Revista da FUNDARTE, Montenegro, p.317-338, ano 19, no 37, Janeiro/Março.

Disponível em: http://.seer.fundarte.rs.gov.br/index.php/RevistadaFundarte/index> 30 de março de 2019. 


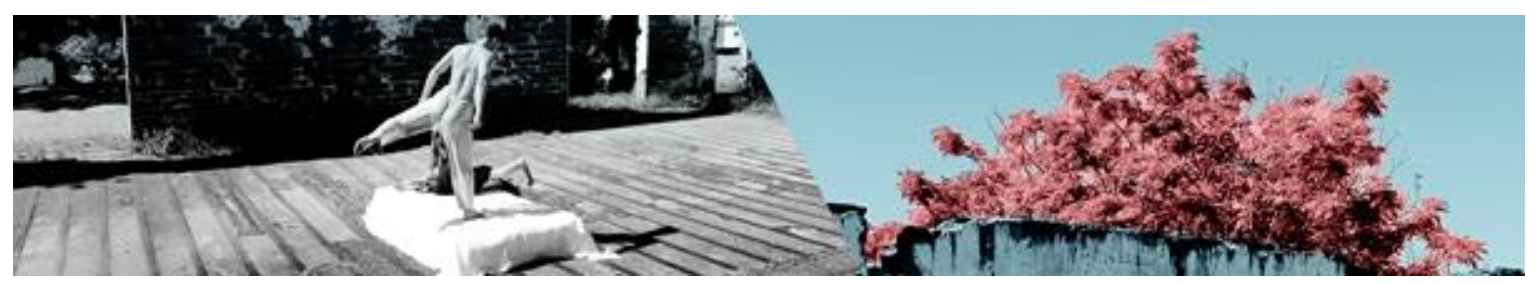

geralmente se identifica uma linha em meia-lua, ou de um semicírculo (em "U"), sendo por isso uma trajetória pendular, como o próprio nome sugere. O pêndulo também pode ser chamado de swing ${ }^{11}$ ou cloche, e designa no geral uma qualidade solta e menos tônica de se mover, indo e vindo de um ponto a outro.

A figura 2 exemplifica algumas dinâmicas pendulares nas aulas de Eva, com os bailarinos partindo da posição em pé.

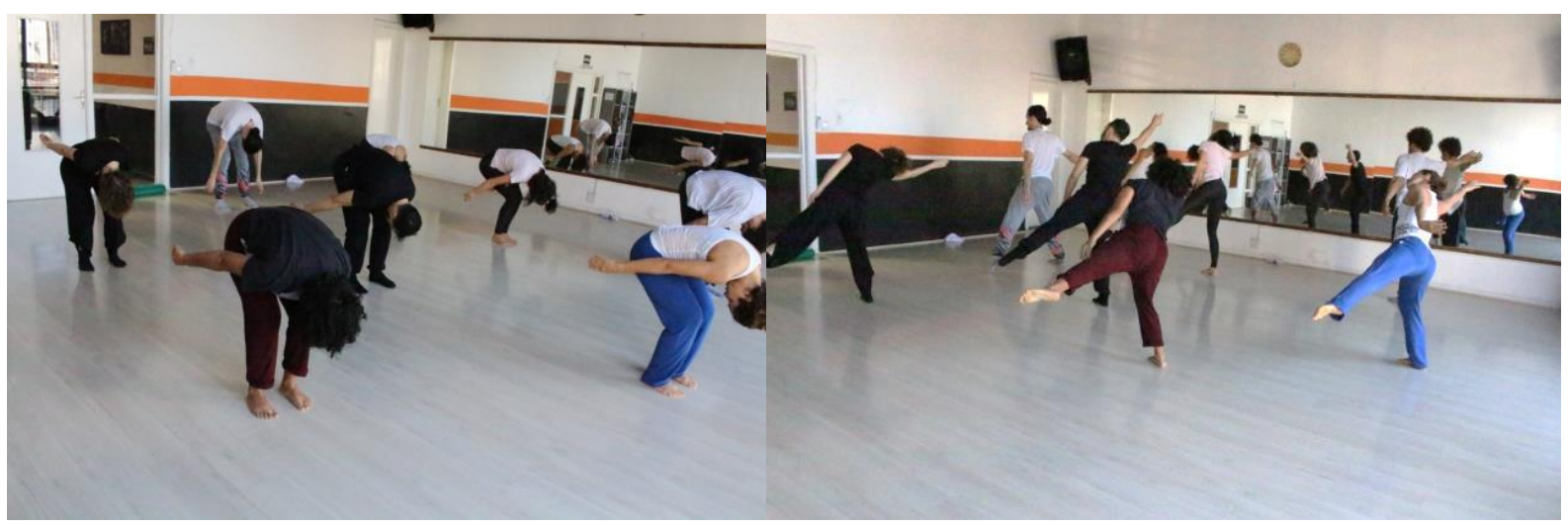

Figura 2. Registros fotográficos de exercícios no quais o pêndulo nos membros superiores (swing de braços) é explorado.

Fonte: Acervo fotográfico da pesquisa.

No quadro à esquerda observamos o pêndulo de braços na fase descendente, ou seja, num momento em que os membros se direcionam para baixo, numa descida. O movimento deste mesmo quadro iniciou com os bailarinos em pé e os braços acima da cabeça direcionados ao alto, resistindo à força da gravidade. A visualidade criada sugerem cordas imaginárias que sustentam os braços para cima sendo cortadas, fazendo com que os braços, agora cedendo ao impulso gravitário, desenhem uma trajetória pendular em "queda livre" à frente do tronco, imprimindo uma linha curva de modo que todo o corpo, neste caso, se engaje junto.

Permitir que a gravidade empurre os braços pra baixo é fundamental nesse exercício. Quando se retira o controle voluntário de segurar o movimento, os segmentos descrevem uma trajetória a partir do seu próprio peso, sendo economizada força e adquirida mais organicidade e fluidez. Quando iniciados pelas mãos e dedos - segmentos da extremidade dos membros superiores - os pêndulos terão um movimento com maior amplitude e um contorno mais periférico. No quadro

11 Segundo o Dicionário Cambridge online, a palavra swing significa se mover facilmente e sem interrupção para frente e para trás (ou para uma direção e outra) (CAMBRIDGE DICTIONARY, 2017).

RESENDE, Fellipe Santos; SILVA, Suzane Weber da. Princípios organizativos de movimento nas aulas de dança contemporânea de Eva Schul. Revista da FUNDARTE, Montenegro, p.317-338, ano 19, no 37, Janeiro/Março.

Disponível em: http://.seer.fundarte.rs.gov.br/index.php/RevistadaFundarte/index> 30 de março de 2019. 


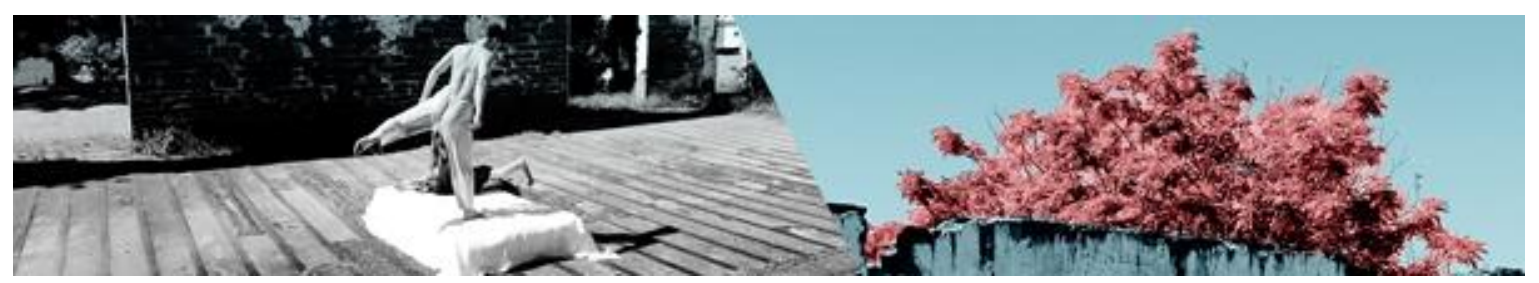

à direita da figura 2 temos um exemplo da fase ascendente do pêndulo do braço direito, contra a gravidade.

A figura 3, por sua vez, exemplifica o pêndulo nas pernas com os bailarinos na posição deitada, sendo traçada outra relação com o espaço. $O$ contato mais horizontal com o chão diminui a interferência da gravidade, facilitando uma qualidade mais rasteira do movimento, o qual tende a ser mais solto, econômico e fluido.

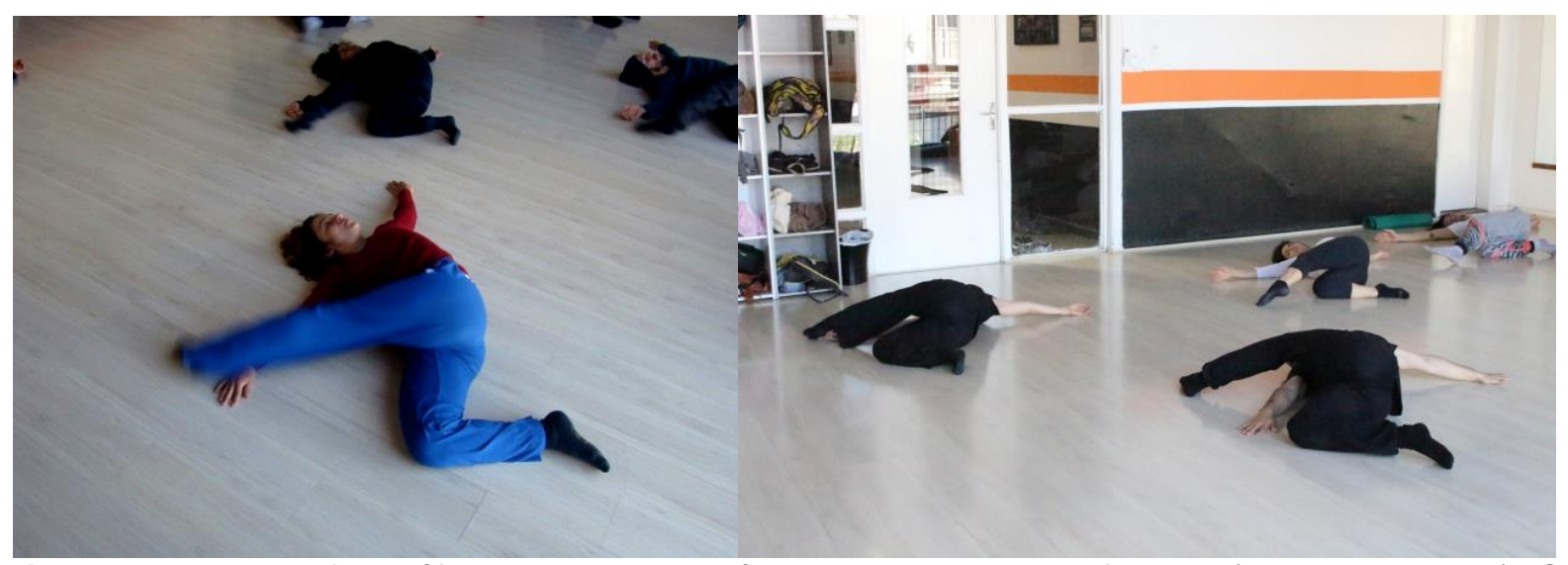

Figura 3. Registros fotográficos ilustrando o pêndulo em membros inferiores (swing de pernas). $O$ membro inferior esquerdo, projetado em ambas as fotos numa extensão (ou semiflexão) para o lado direito, encontra-se no ponto final de sua trajetória pendular no chão. Ele sai desta altura onde está fotografado e ao retornar à linha mediana do $\operatorname{corpo}^{12}$ se dobra voltando à posição de repouso. A seguir, o membro inferior direito que está em repouso, se projeta estendido ou parcialmente dobrado para o lado esquerdo do corpo, numa trajetória pendular, com o pé buscando um alcance bem periférico. Em ambas as imagens o pêndulo é executado com o tronco, cabeça e membros superiores, sendo a base estável.

Fonte: Acervo fotográfico da pesquisa.

O swing de pernas ocorre de maneira geral em alternância de um lado para o outro, mas pode avançar para uma transição de nível de altura, encadeando uma sequência diferente. A pelve, por sua vez, fica num ponto intermediário fazendo pequenas torções para o lado da perna que realiza o pêndulo, trabalhando indiretamente uma espiral na base da coluna vertebral. A intenção que guia esse movimento deve prezar por deixar o membro de ação livre de esforços desnecessários, pois a ideia do pêndulo é valer-se do peso do próprio segmento para ditar o ritmo e a logística da trajetória pendular a ser desenhada no espaço.

\footnotetext{
${ }^{12}$ A linha mediana do corpo divide-o imaginariamente em duas metades iguais: direita e esquerda.
}

RESENDE, Fellipe Santos; SILVA, Suzane Weber da. Princípios organizativos de movimento nas aulas de dança contemporânea de Eva Schul. Revista da FUNDARTE, Montenegro, p.317-338, ano 19, no 37, Janeiro/Março.

Disponível em: http://.seer.fundarte.rs.gov.br/index.php/RevistadaFundarte/index> 30 de março de 2019. 


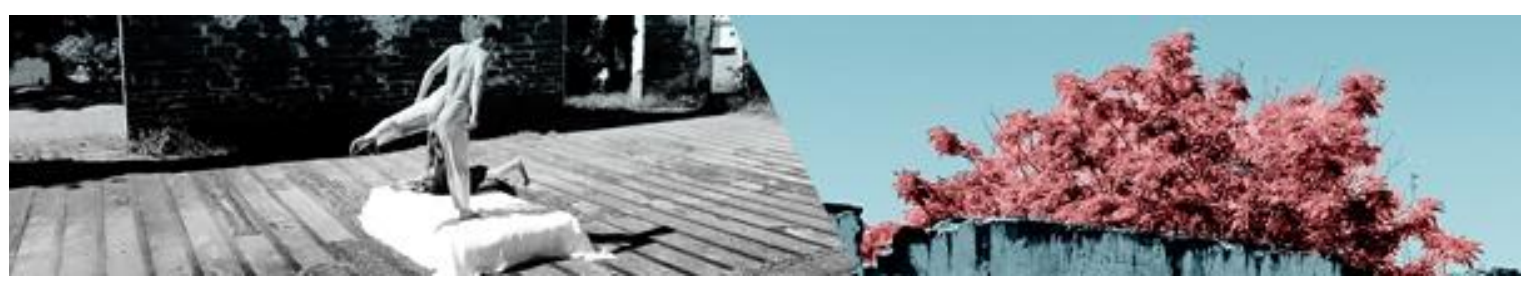

Para quem executa o movimento há uma sensação de lançamento rasteiro da perna; um "deixar ir" que permite a soltura de parte da musculatura do membro que pendula.

Dando seguimento às facetas do estudo do peso e do esforço mínimo, chegamos ao momentum $^{13}$. Na dança este termo geralmente diz respeito a um ponto específico presente em um movimento circular de membros superiores, entre duas fases de aceleração do movimento, ou entre o fim de um círculo completo de braços e o início de outro. Pode ser visto como uma paragem temporária, tendo a qualidade de um "respiro", uma suspensão. Por ser geralmente explorado em sequências circulares de braços, o momentum está associado ao exercício das chamadas overcurves, ou curvas por cima, no qual um braço está sempre logo em seguida do outro, "a reboque" (figura 4).

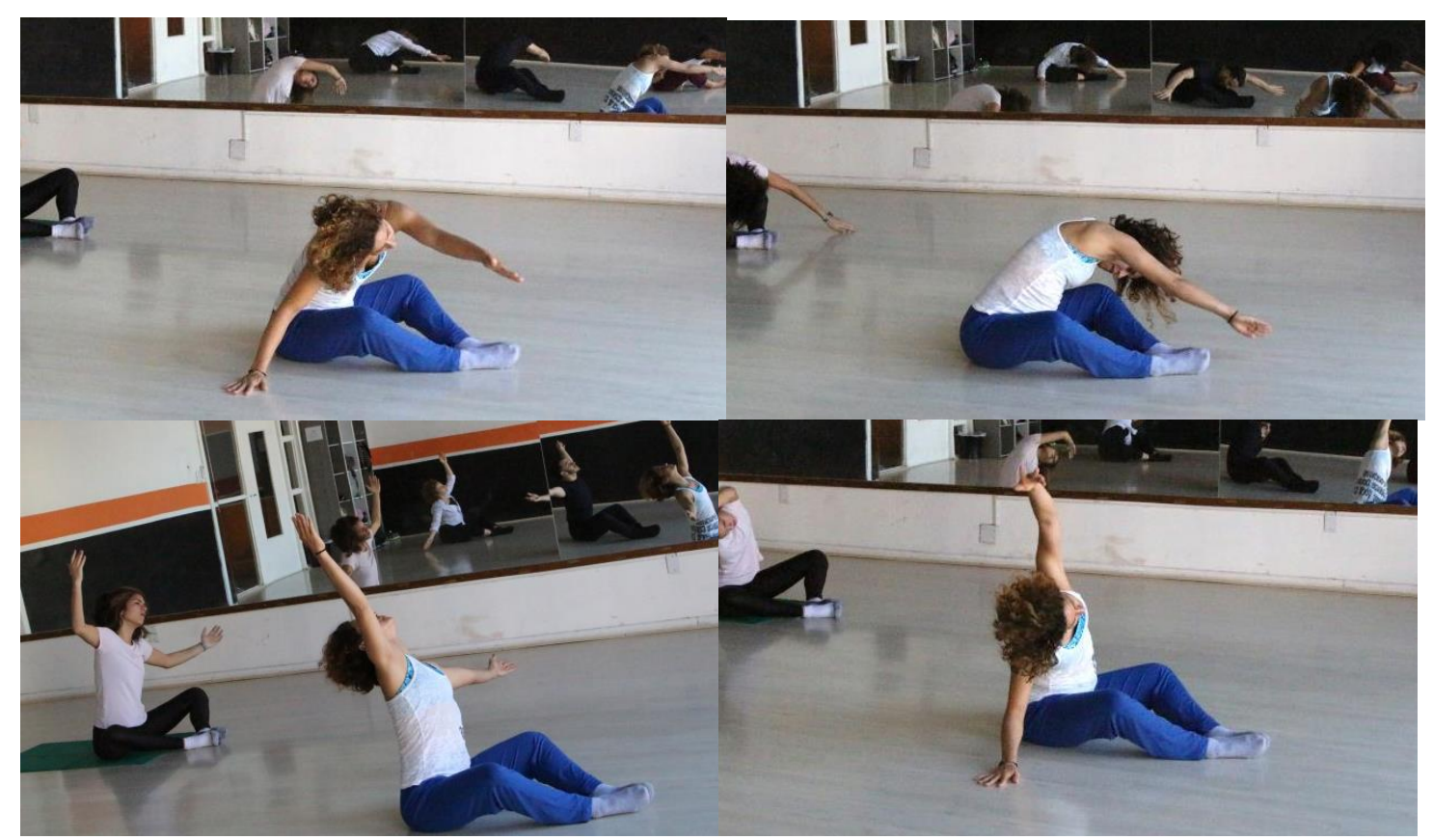

Figura 4. Registros da dinâmica do momentum no exercício da curva por cima. Fonte: Acervo fotográfico da pesquisa.

É precedido por um impulso que realiza o movimento circular de braços (fase ascendente), e dá-se no momento da redução passageira do tempo, quando ambos

$13 \mathrm{O}$ momentum aparece na literatura como um conceito relacionado às leis de Newton, possuindo equações e raciocínios físicos específicos para ser precisamente calculado (HAMILTON, LEWIS e LUTTGENS, 2013). No entanto, atentamos à instância qualitativa do momentum, não se preocupando em contemplar essas representações matemáticas. O momentum também é bastante conhecido nas técnicas do contato improvisação e nos textos de seus praticantes, com o mesmo sentido de suspensão.

RESENDE, Fellipe Santos; SILVA, Suzane Weber da. Princípios organizativos de movimento nas aulas de dança contemporânea de Eva Schul. Revista da FUNDARTE, Montenegro, p.317-338, ano 19, no 37, Janeiro/Março.

Disponível em: http://.seer.fundarte.rs.gov.br/index.php/RevistadaFundarte/index> 30 de março de 2019. 


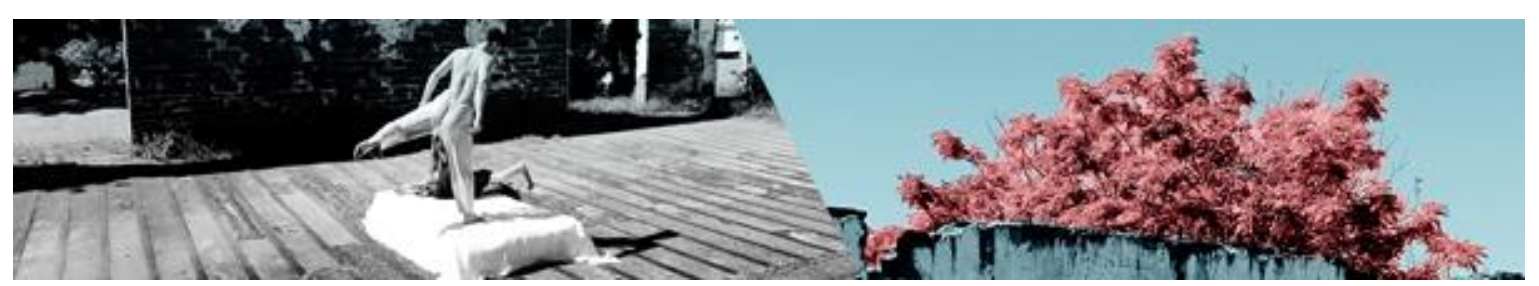

os braços estão no nível mais alto da trajetória - acima da cabeça, em direção ao teto - e sua força de ação se "anula" brevemente com a força da gravidade. Adiante, reaceleram de volta ao desenho circular que estavam executando (entrando na fase descendente, para o chão) ou pausam, voluntariamente, não completando sua trajetória.

Identifica-se uma dinâmica equivalente no movimento mecânico da montanha russa, num parque de diversões. Quando a pensamos partindo do solo e engrenando numa trajetória ascendente em diagonal, notamos a resistência da força gravitacional sobre o carrinho e as pessoas que nele estão. Em um dado momento o carrinho não encontrará essa mesma resistência, e passará por um momento de suspensão, precedente à "queda": o momentum.

Embora pareça um movimento creditado unicamente aos membros superiores, encontramos na ação da cabeça um papel fundamental, uma vez que ao se inclinar perifericamente à frente, para longe do centro do corpo, a cabeça auxilia os braços a ganharem velocidade e organicidade no seu timing.

Dentro do corrente princípio aqui discutido também está um exercício tão importante quanto os movimentos já mencionados: o lançamento e abandono de um segmento corporal no espaço. Essa noção é particularmente difícil de ser assimilada, pois os bailarinos geralmente apresentam o hábito de conduzir e controlar exageradamente um segmento quando o mesmo é lançado/"jogado" no espaço. Por meio desse exercício a própria relação com a gravidade e o entendimento do peso são mais bem desenvolvidos.

Estando deitados no chão com os quadris e joelhos dobrados, pés apoiados no chão, e braços ao longo do corpo, os bailarinos lançam separadamente os membros superiores e inferiores pra cima: primeiramente um a um, alternando os lados (quadro esquerdo - figura 5) e então simultaneamente com todos os membros (quadro direito - figura 5).

RESENDE, Fellipe Santos; SILVA, Suzane Weber da. Princípios organizativos de movimento nas aulas de dança contemporânea de Eva Schul. Revista da FUNDARTE, Montenegro, p.317-338, ano 19, no 37, Janeiro/Março.

Disponível em: http://.seer.fundarte.rs.gov.br/index.php/RevistadaFundarte/index> 30 de março de 2019. 

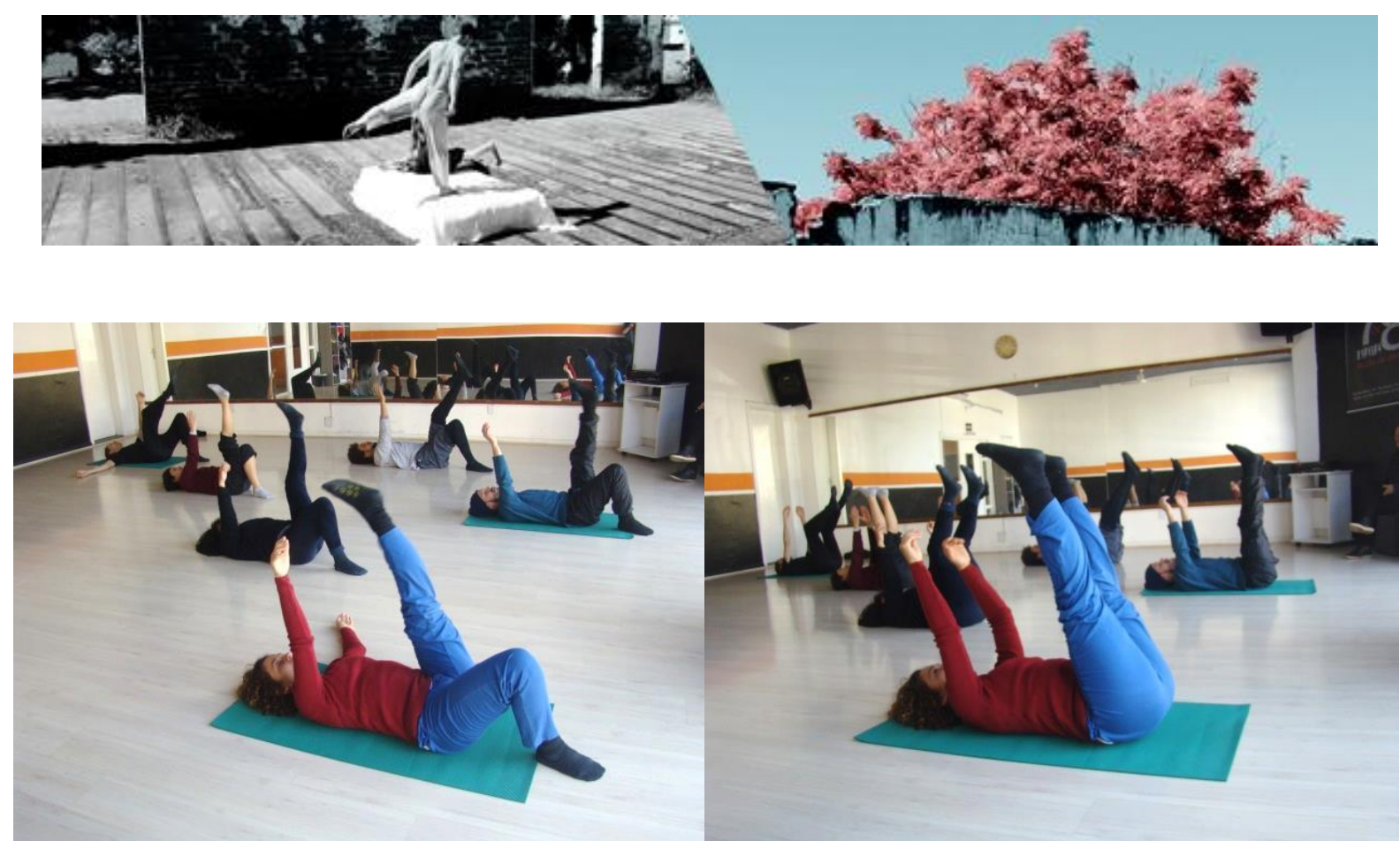

Figura 5. Registros fotográficos ilustrando o exercício de lançar um segmento e abandoná-lo para cair de volta ao chão.

Fonte: Acervo fotográfico da pesquisa.

Eva Schul sugere que suprimamos o impulso de controlar a fase de descida do segmento lançado, permitindo que a força gravitária seja a única responsável pelo retorno do membro ao solo, a partir do seu peso propriamente dito, em "abandono" até cair de volta ao chão. A sensação da projeção e queda combinadas aumenta exponencialmente a percepção do peso nos segmentos trabalhados.

Todos esses exercícios e elementos são estratégias de estudo do peso que configuram importantes referências nas coreografias propostas no segmento final da aula, quando os princípios organizativos apreendidos são aplicados com maior evidência, e se relacionam de maneira mais palpável com os propósitos técnicos, estéticos e poéticos da professora.

Esse tópico apresenta por fim o estudo do esforço mínimo. Aqui, sugerimos extrapolar a ideia de esforço como maior empenho ou excesso de força colocada em determinada ação, e evitar a compreensão de esforço mínimo como a não necessidade de esforço. No campo da dança a noção de esforço pode ir além das compreensões comumente assumidas, sendo um conceito chave para decifrar as qualidades do movimento, auxiliando numa gestão inteligente dos esforços, resultando em movimentos de maior qualidade e eficácia e favorecendo uma maior longevidade do bailarino em seu fazer dança.

Para Laban (1978), sempre há um esforço quando agimos, mesmo em ações como flutuar, onde o esforço corresponde à um estado de leveza, um peso leve. $\mathrm{O}$

RESENDE, Fellipe Santos; SILVA, Suzane Weber da. Princípios organizativos de movimento nas aulas de dança contemporânea de Eva Schul. Revista da FUNDARTE, Montenegro, p.317-338, ano 19, no 37, Janeiro/Março.

Disponível em: http://.seer.fundarte.rs.gov.br/index.php/RevistadaFundarte/index> 30 de março de 2019. 


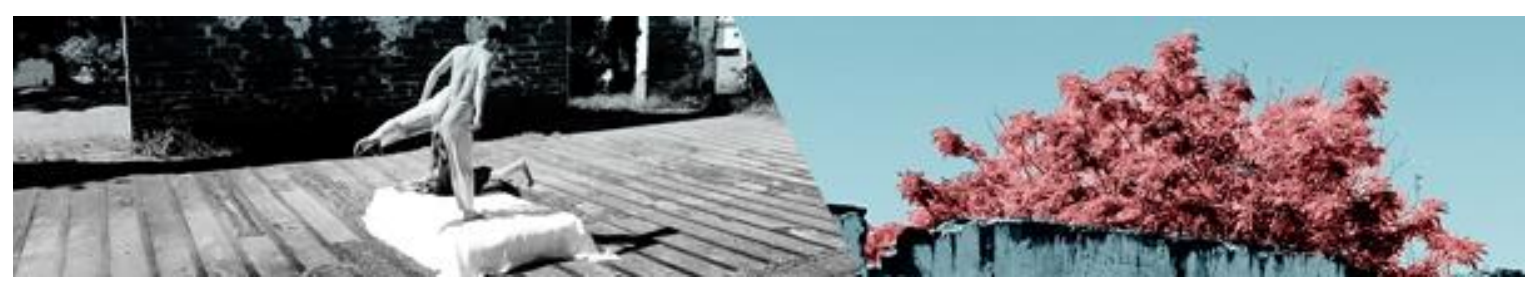

teórico pontua que a noção de esforço está centrada nas possíveis alterações e nuances que os fatores de movimento peso, espaço, tempo e fluência revelam de modo singular. Na análise de nosso estudo para a compreensão da técnica de Eva Schul, tal princípio organizativo parte do entendimento de que o corpo deve usar seu peso de maneira inteligente e econômica, sem ativação de musculaturas desnecessárias à realização do movimento. Em consonância a esse pensamento, a também pioneira da dança gaúcha Cecy Franck (2013) indica que o uso adequado dessa energia é um dos princípios fundamentais que norteiam a aprendizagem técnica em dança, estando o foco do corpo dançante direcionado para a quantidade de força necessária à execução do movimento desejado. Nessa dinâmica se busca recorrer a certa maestria sobre o movimento, na qual o corpo conhece primeiro o caminho para realizá-lo, para então fazê-lo de maneira que economize energia.

Essa logística de aprendizado envolvendo a memorização e a repetição consciente é uma conduta presente nas aulas de Eva Schul. Os exercícios compõem uma aula de estrutura coreografada, exigindo disponibilidade para apreensão visual e cinestésica ${ }^{14}$ dos movimentos por parte dos bailarinos. Os corpos dançantes vão adaptando os caminhos técnicos propostos conforme as habilidades possíveis na aula em questão ou período evolutivo do seu desempenho.

Um exemplo que mais evidencia a aplicação do estudo do esforço mínimo é o deslocamento em torção no nível baixo (figura 6).

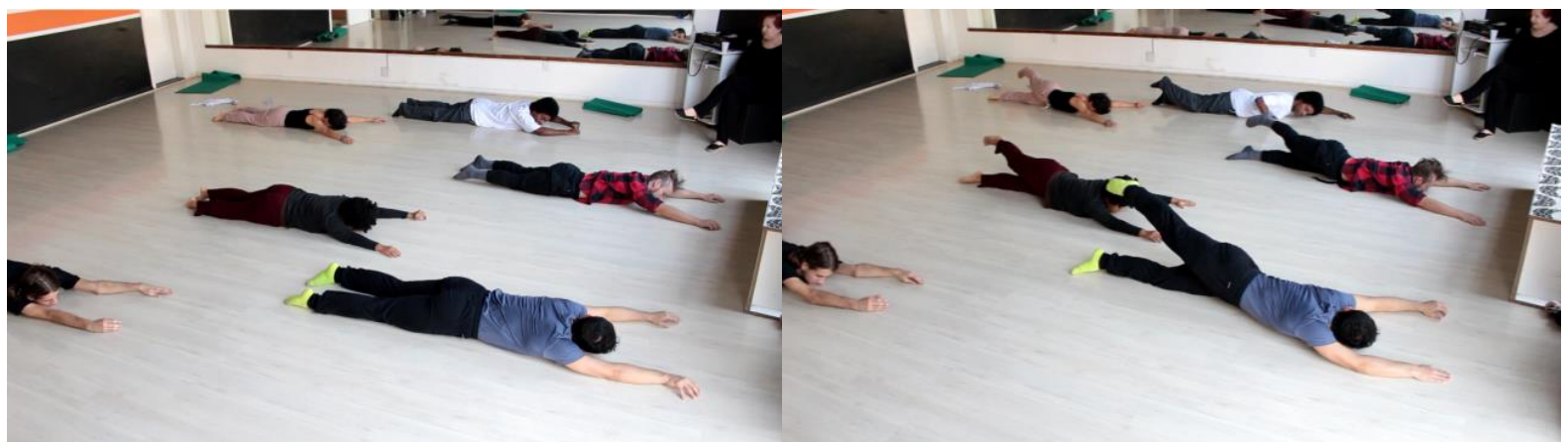

Figura 6. Capturas de tela de registros videográficos do exercício de deslocamento no nível baixo (parte I).

Fonte: Acervo fotográfico de pesquisa.

\footnotetext{
${ }^{14}$ Tais movimentos são ensinados ora por demonstração ou marcação, ora por orientação verbal e imagética. Em ambos os casos, os bailarinos vão compreendendo as sutilezas, assimilando os comandos e visualidades sugeridas, e se aproximando - a seu ritmo - da sequência proposta pela mestra.
}

RESENDE, Fellipe Santos; SILVA, Suzane Weber da. Princípios organizativos de movimento nas aulas de dança contemporânea de Eva Schul. Revista da FUNDARTE, Montenegro, p.317-338, ano 19, no 37, Janeiro/Março.

Disponível em: http://.seer.fundarte.rs.gov.br/index.php/RevistadaFundarte/index> 30 de março de 2019. 


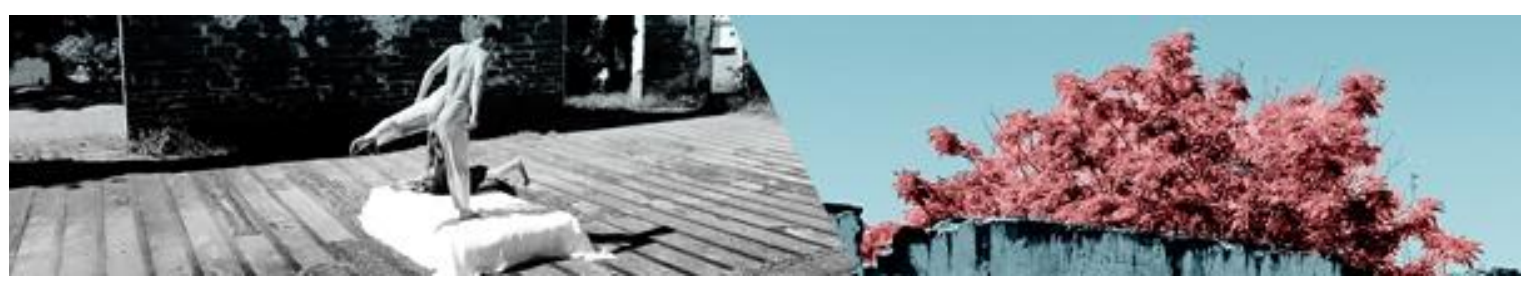

Os bailarinos estão em posição deitada (quadro esquerdo - figura 6), e com a face anterior do corpo para baixo iniciam o movimento de torcer o corpo até se virarem para cima a partir do pé direito (quadro direito - figura 6).

$O$ peso do corpo vai sendo transferido gradual e sequencialmente de articulação em articulação, passando por todo o membro inferior, tronco, e membro superior, que está em oposição, resistindo ao movimento de virar o corpo para cima (quadro esquerdo - figura 7). A face anterior do corpo só irá virar completamente para cima quando toda a linha de oposição entre a extremidade do pé direito e da mão contrária a ele estiver dissipada (quadro direito - figura 7).

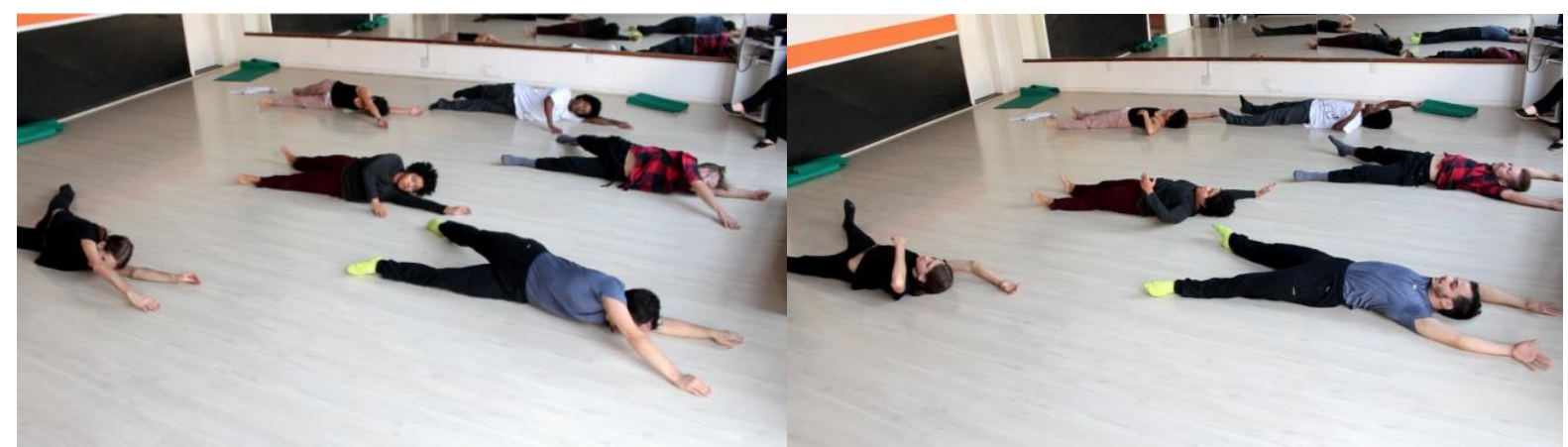

Figura 7. Capturas de tela de registros videográficos do exercício de deslocamento no nível baixo (parte II).

Fonte: Acervo fotográfico de pesquisa.

Estando com a face anterior do corpo para cima, a mão esquerda dos bailarinos iniciará o movimento de torcer o corpo até virá-lo para baixo (figura 8), repetindo a dinâmica espiralada num ritmo orgânico que não deve negligenciar a passagem gradual por cada articulação e segmento existente na linha da torção. Há uma busca de isolamento e estabilização do movimento pelas partes do corpo que não executam o deslocamento em torção de modo aparente.

RESENDE, Fellipe Santos; SILVA, Suzane Weber da. Princípios organizativos de movimento nas aulas de dança contemporânea de Eva Schul. Revista da FUNDARTE, Montenegro, p.317-338, ano 19, no 37, Janeiro/Março.

Disponível em: http://.seer.fundarte.rs.gov.br/index.php/RevistadaFundarte/index> 30 de março de 2019. 

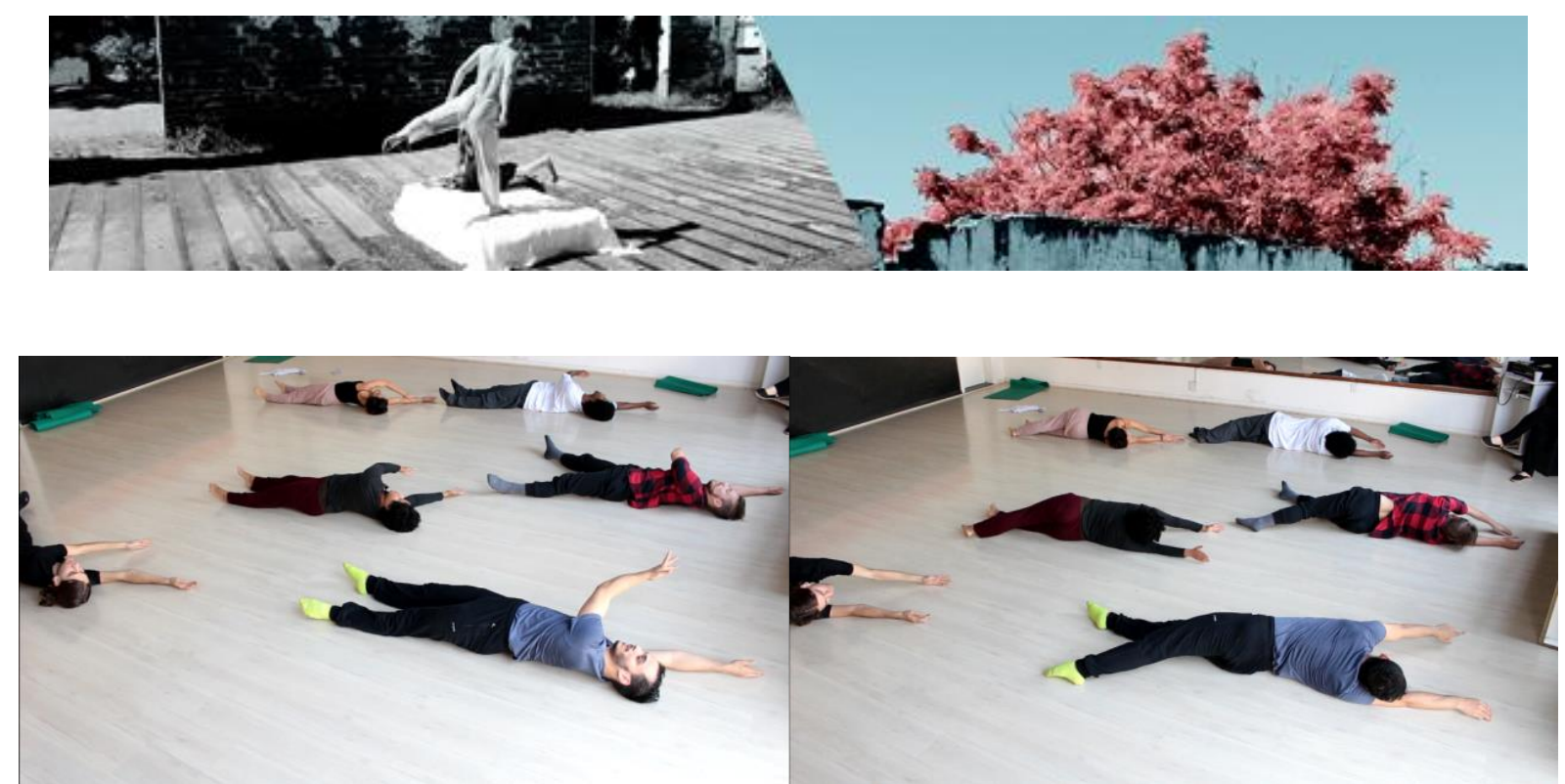

Figura 8. Capturas de tela de registros videográficos do exercício de deslocamento no nível baixo (parte III).

Fonte: Acervo fotográfico de pesquisa.

O exercício ocorre de maneira segmentada, porém em fluxo ininterrupto, com um segmento sendo levado pelo outro "a reboque". A qualidade rasteira e relaxada, porém não passiva, é importante nesse exercício. Quanto mais próximo do chão ele ocorre, menor a força exigida contra a gravidade, e mais inteligente o uso das tensões e vetores intrínsecos ao deslocamento. O estudo do esforço mínimo ocorre exatamente nessa modulação econômica das forças empreendidas no movimento, de forma que nenhuma tensão desnecessária seja adicionada nesse ato de virar-se para mudar de lugar. Uma vez se apropriando dessa noção, os bailarinos passam a fazer o exercício de um jeito deliberadamente orgânico, fluído e guiado somente pelo ritmo que cada peso e cada corpo imprimem nesse deslocar-se.

O estudo do esforço mínimo pode ser considerado ainda consonante à noção de oposição e contralateralidade trazida por Irmgard Bartenieff, com quem Eva teve uma breve, porém significativa formação numa das vezes que morou em Nova York (EUA), na década de noventa. Daí surgiram importantes influências sobre tópicos em postura corporal, exercícios terapêuticos, alinhamentos funcionais e abordagens somáticas, fortalecendo um aspecto perceptivo e ainda mais sensível da fisicalidade e fluidez já identitárias em suas aulas e seu fazer dança.

No referido exercício de oposição e contralateralidade (figura 9) o braço desenha espacialmente uma linha de tensão oposta à linha da perna contrária, configurando uma espiral/torção na coluna vertebral e tronco, segmentos que agem como intermediários no trânsito de esforços e energias mais periféricas (HAAS, 2012).

RESENDE, Fellipe Santos; SILVA, Suzane Weber da. Princípios organizativos de movimento nas aulas de dança contemporânea de Eva Schul. Revista da FUNDARTE, Montenegro, p.317-338, ano 19, no 37, Janeiro/Março.

Disponível em: http://.seer.fundarte.rs.gov.br/index.php/RevistadaFundarte/index> 30 de março de 2019. 

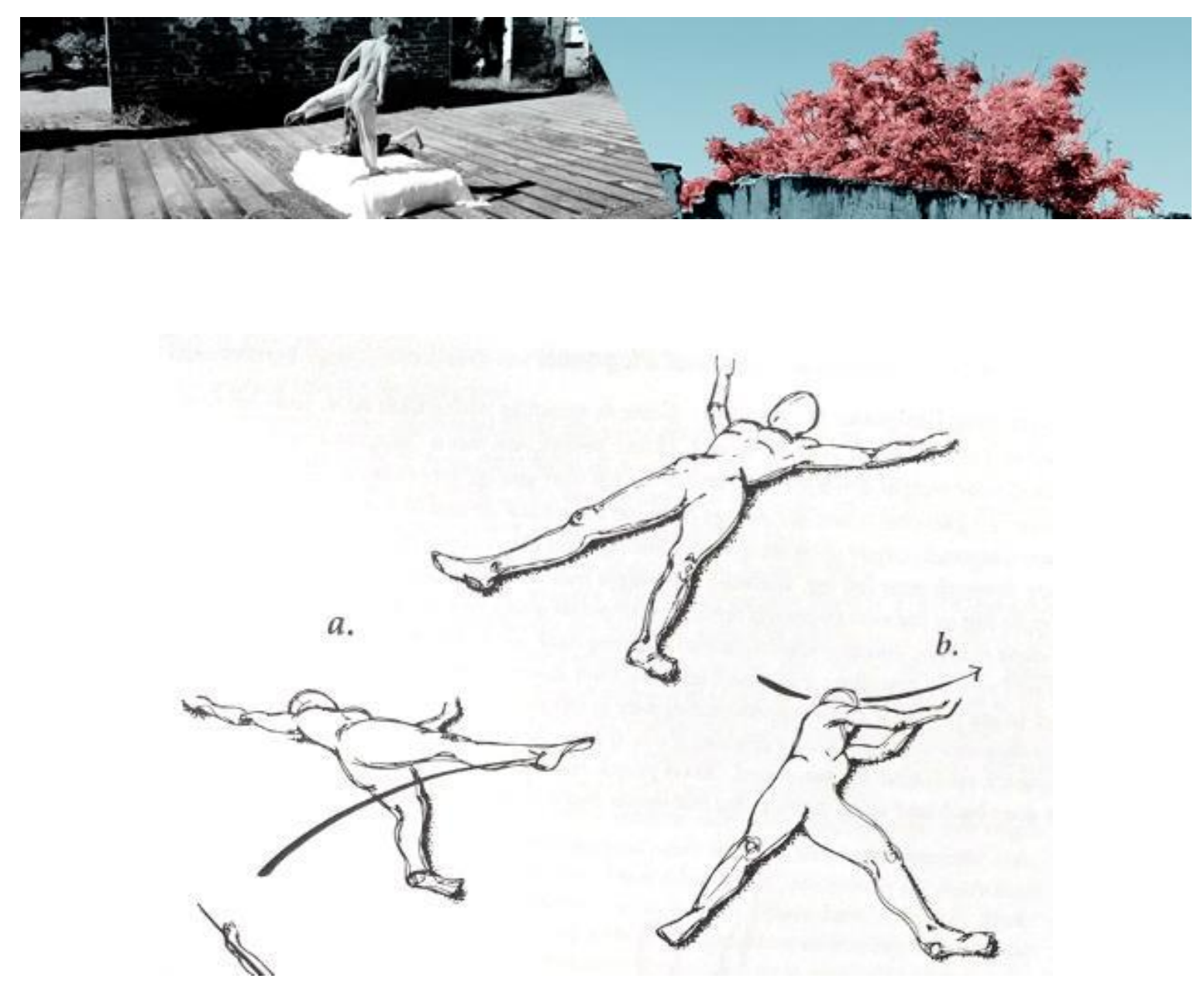

Figura 9. Imagem de livro representando movimentos em que a contralateridade e oposição de membros é explorada nos exercícios de Bartenieff.

Fonte: HACKNEY, 2003.

A mestra Eva Schul indica o peso e o esforço mínimo como fundamentais de serem estudados para que os conceitos trabalhados em suas aulas sejam incorporados. Ela relata que uma das ações principais é não fazer força onde não precisa, sendo essa uma das questões que ela considera mais orgânicas de seu trabalho: "Quanto menos esforço, mais o corpo vai. O corpo se entrega e faz um movimento bonito quando está entregue às forças da gravidade, vetoriais e tudo mais" (SCHUL, 2017).

\section{Estudo do fluxo e da qualidade de fluência}

Como já mencionado por Soares (2014), o fator fluxo no trabalho de Eva Schul é um elemento marcante e muito característico de sua técnica. A própria mestra corrobora essa questão em seus discursos, sendo a qualidade fluída dos movimentos um fator presente e singularmente aplicado no conjunto de suas proposições, tanto em sala de aula quanto em suas produções coreográficas.

RESENDE, Fellipe Santos; SILVA, Suzane Weber da. Princípios organizativos de movimento nas aulas de dança contemporânea de Eva Schul. Revista da FUNDARTE, Montenegro, p.317-338, ano 19, no 37, Janeiro/Março.

Disponível em: http://.seer.fundarte.rs.gov.br/index.php/RevistadaFundarte/index> 30 de março de 2019. 


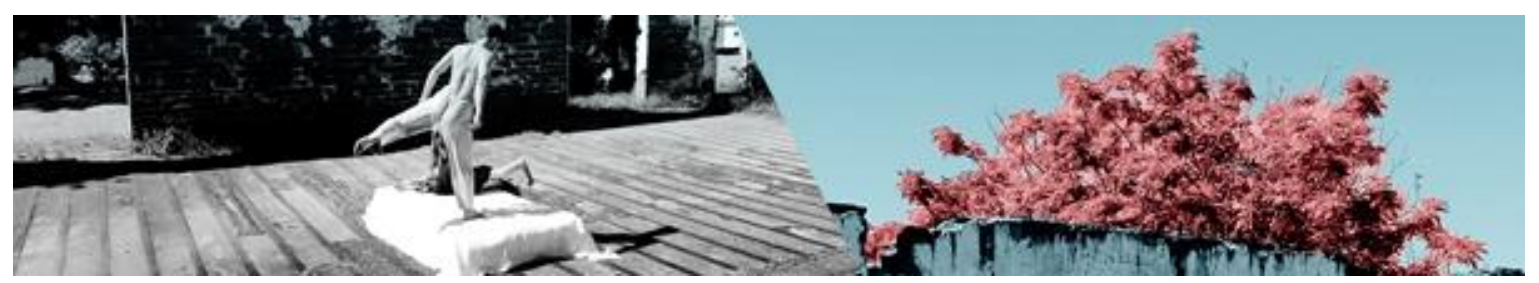

Sendo determinante da qualidade a ser apresentada pelo corpo dançante, o fator fluxo refere-se à tensão muscular usada para deixar o movimento fluir, podendo ser designado como fluxo livre/não interrompido ou fluxo controlado (FERNANDES, 2006), e dizendo respeito ao encadeamento dos movimentos. Além de estar relacionado ao sentimento e também à emoção, o fator fluxo relaciona-se com o "como" do movimento (FERNANDES, 2006), conferindo fortes traços dramatúrgicos à dança onde é impresso.

A qualidade de fluência - ou fluidez - é fortemente influenciada pela ordem em que são acionadas as diferentes partes do corpo (LABAN, 1978), e no trabalho técnico proposto por Eva, com a modulação sequencial dos movimentos de modo contínuo e engajado, um verdadeiro exercício de encontrar a conectividade entre os elementos que compõe uma dança. Essa predileção da técnica de Eva valoriza exercícios e sequências com fluxo livre, dando ao intérprete e ao espectador (SOARES, 2014), e de forma estendida, ao bailarino e ao observador da aula, a sensação de continuidade ou não interrupção dos movimentos.

O estudo dessa qualidade exige um estado de corpo que pratique a ação de deixar fluir, de deixar os segmentos serem conduzidos num ritmo orgânico, de acordo com suas próprias dimensões, volumes e demais traços. Do mesmo modo, ela não implica um simples deixar que as coisas aconteçam, sem um mínimo de propriedade ou consciência sobre as intenções de estudar essa dinâmica. É necessária uma refinada atenção e noção do peso de cada parte do corpo para permitir que os segmentos desenhem as linhas desejadas na massa do espaço e sejam conduzidos de maneira menos "dura".

Estudar o fluxo para atingir uma qualidade de fluência nos movimentos diz respeito a ter atenção ampliada às transições e espaços do 'entre', existentes no nosso mover. Em muitos exercícios os bailarinos são estimulados por Eva a não deixarem o movimento staccato, de forma que a transição de um movimento para o outro não seja evidenciada. Nesse sentido, espera-se que este 'entre' seja suavizado e ocorra sem distinções claras de quando um movimento termina e o outro inicia.

RESENDE, Fellipe Santos; SILVA, Suzane Weber da. Princípios organizativos de movimento nas aulas de dança contemporânea de Eva Schul. Revista da FUNDARTE, Montenegro, p.317-338, ano 19, no 37, Janeiro/Março.

Disponível em: http://.seer.fundarte.rs.gov.br/index.php/RevistadaFundarte/index> 30 de março de 2019. 


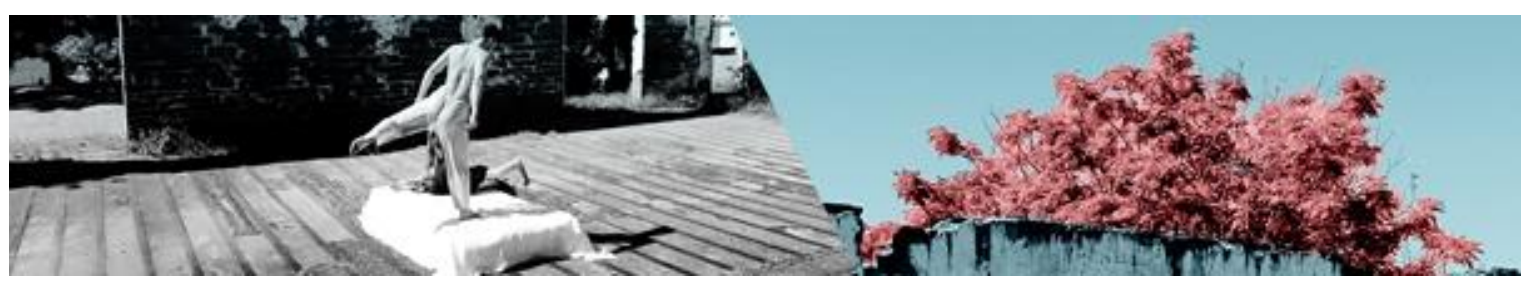

Nas aulas, muitos exercícios preparatórios envolvendo o estudo do fluxo incluem mobilizações isoladas a articulações específicas, movimentos que trocam de nível de altura, sequências de acumulação, saltos, giros, e deslocamentos. Este princípio faz eco ao estudo da modulação tônica e do isolamento segmentar (princípio não abordado neste artigo), à medida que preza por uma sensação mais articular do movimento (com tônus voluntariamente colocado como mais "solto", "frouxo", "fluido"), do que muscular (com tônus mais explosivo e de qualidade muito contraída/rígida).

Exemplos possíveis para esse o estudo do fluxo e da qualidade de fluência incluem o exercício de mobilização articular de membros superiores com torção de tronco (figura 10), e o de mobilização de quadris (figura 11). Em ambos os exemplos os bailarinos devem carregar a intenção já descrita de não explicitar quando um movimento acaba e o outro inicia. A fluidez presente nos intervalos dos movimentos deve ser a condutora mor do exercício.

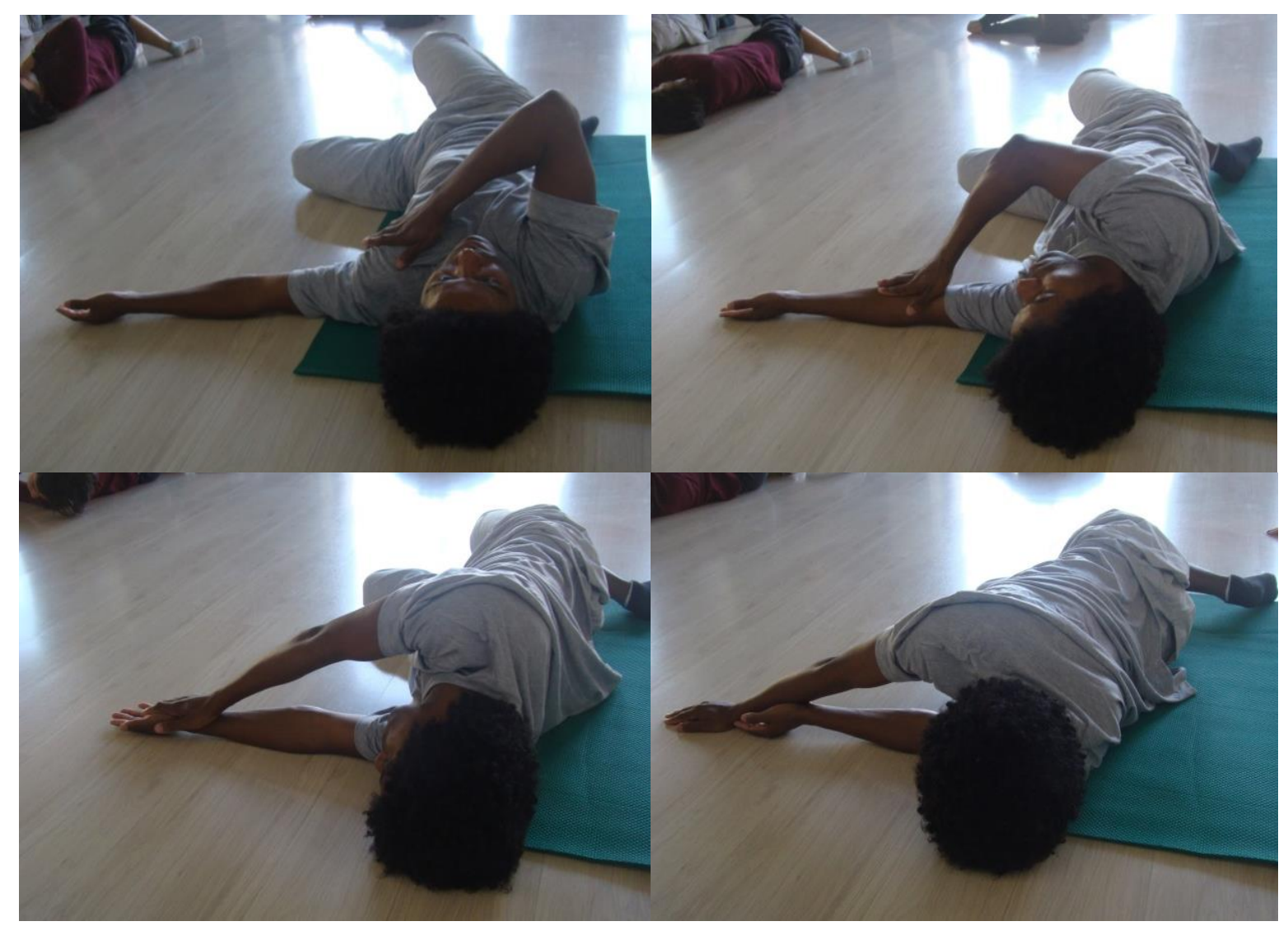

Figura 10. Registros fotográficos compondo sequência de mobilização articular de membros superiores com torção de tronco. Embora os segmentos sejam acionados separadamente (dedos,

RESENDE, Fellipe Santos; SILVA, Suzane Weber da. Princípios organizativos de movimento nas aulas de dança contemporânea de Eva Schul. Revista da FUNDARTE, Montenegro, p.317-338, ano 19, no 37, Janeiro/Março.

Disponível em: http://.seer.fundarte.rs.gov.br/index.php/RevistadaFundarte/index> 30 de março de 2019. 


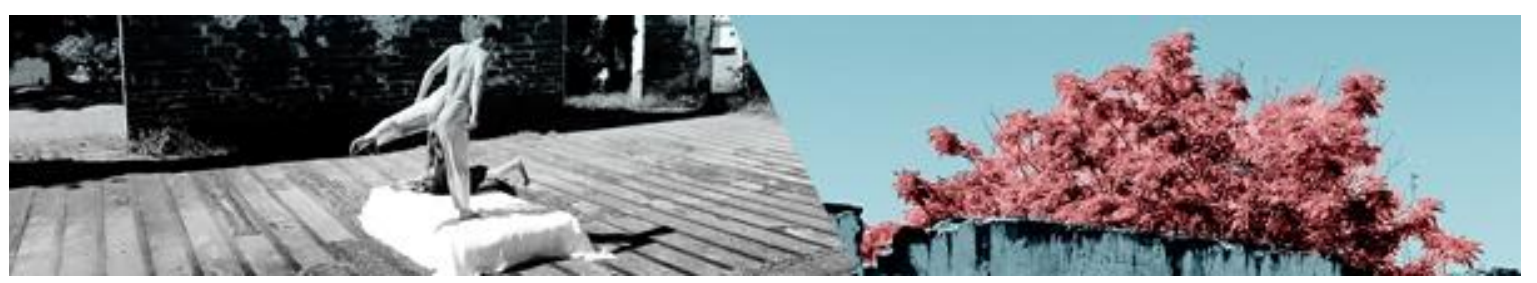

mão, punho, cotovelo, ombro) o intervalo entre o movimento de cada segmento é suavizado, de forma que ele ocorra com fluência, sem paradas evidentes.

Fonte: Acervo fotográfico da pesquisa.

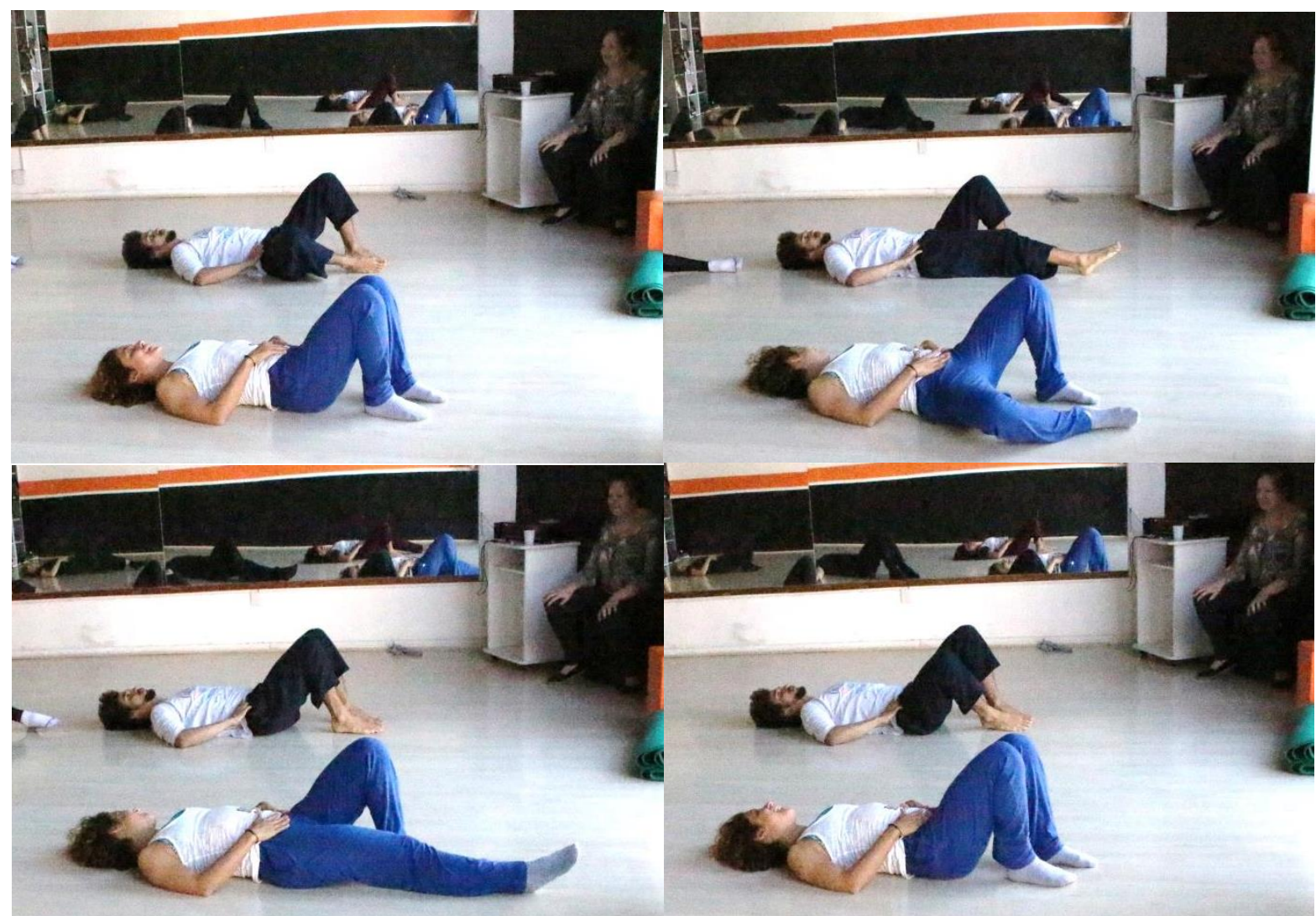

Figura 11. Registros fotográficos do exercício de mobilização de quadris. Os movimentos de rotação externa e interna, flexão e extensão são explorados nesses segmentos com o fluxo do tipo não interrompido.

Fonte: Acervo fotográfico da pesquisa.

As transições devem encontrar-se encadeadas num fluxo que é significativamente livre para não destacar nenhum movimento dentro da sequência como um todo, mas ativo o suficiente para não haver abandono do segmento mobilizado. A condução sensível e uma atitude consciente dos bailarinos são, pois, fundamentais para que os movimentos em fluxo livre não sejam experiências passivas de corpo.

Nesses dois exemplos, é interessante notar que a virtuosidade não depende necessariamente de membros com grandes amplitudes, mas resulta da qualidade da fluência e do ritmo organicamente encadeado, algo bastante sutil, que explora uma

RESENDE, Fellipe Santos; SILVA, Suzane Weber da. Princípios organizativos de movimento nas aulas de dança contemporânea de Eva Schul. Revista da FUNDARTE, Montenegro, p.317-338, ano 19, no 37, Janeiro/Março.

Disponível em: http://.seer.fundarte.rs.gov.br/index.php/RevistadaFundarte/index> 30 de março de 2019. 


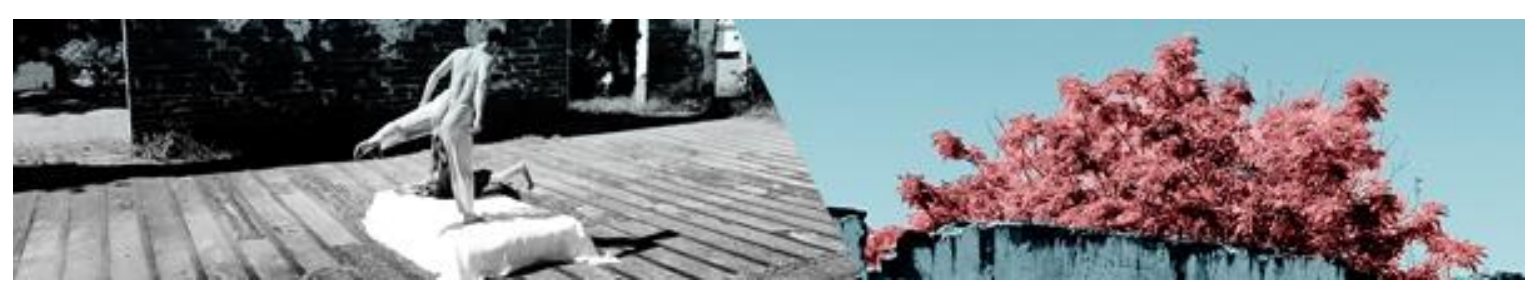

poética de conectividade entre as partes componentes de uma sequência coreografada, e numa visão macro, as partes integrantes do sujeito que dança.

\section{Dançando movimentos por ora conclusivos}

Embora apresente uma abordagem metodológica de aplicação única, esta pesquisa busca seguir desdobrando reflexões produtivas a partir dos materiais oriundos desta rica técnica corporal, intencionando subsidiar de alguma forma pesquisas futuras e produções na área do movimento dançado.

Os princípios organizativos apresentados nesse artigo devem ser pensados em constante relação, tendo sido separados somente para fins de análise. Por estarem sobrepostos em vários pontos das aulas, se interdependem, complementam e dão suporte, podendo inclusive ser explicados um em virtude do outro, dada tamanha intersecção existente.

Eles sugerem caminhos específicos para o corpo transitar tanto no vocabulário de elementos existentes em suas aulas quanto em aulas de outros gêneros/estilos, motivo pelo qual se encontram presentes muitos bailarinos com bases técnicas diferentes. Independente do background formativo os corpos dançantes acessam essas propriedades de modo singular, sendo possível que alunos de diferentes níveis técnicos e gerações - desde a menoridade até bailarinos com mais de cinquenta anos - incorporem e se apropriem dessas noções e subsídios para dançar, sugerindo uma potente atualidade e acessibilidade da técnica em questão.

Assim como Dantas (1999), compreendemos que a prática do aprendizado coreográfico é uma maneira de formar corpos dançantes e, nesse sentido, uma ação formativa. As aulas de Eva Schul oferecem ferramentas que nos auxiliam a brincar com a gravidade, a fluir nas sensações, a trocar experiências. Em cada repetição coreografada e estudo de um princípio sua técnica age como um modo de construir danças, de formar corpos com subsídios de arte.

RESENDE, Fellipe Santos; SILVA, Suzane Weber da. Princípios organizativos de movimento nas aulas de dança contemporânea de Eva Schul. Revista da FUNDARTE, Montenegro, p.317-338, ano 19, no 37, Janeiro/Março.

Disponível em: http://.seer.fundarte.rs.gov.br/index.php/RevistadaFundarte/index> 30 de março de 2019. 


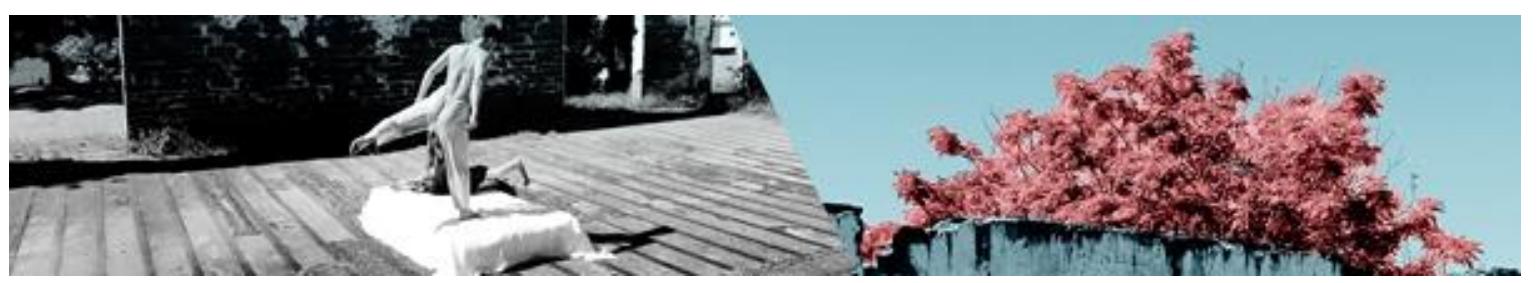

Sua ampla trajetória enquanto pedagoga reúne mais de quarenta anos de pesquisa na matéria da carne, numa modernidade contemporânea que busca aprender, ensinar e ampliar horizontes em torno dos movimentos dançáveis por um indivíduo.

Cada um dos caminhos aqui apresentados supõe uma atitude de corpo que, num panorama maior reporta à técnica de Eva Schul, configurando uma identidade e assinatura estética para suas aulas. Há assim um constante movimento de princípios se dando as mãos para conferir estados de corpo singulares a essa técnica, estados de corpo dançando Eva Schul.

\section{Referências:}

BRENNAN, M.A. Every little movement has a meaning all its own - Movement analysis in dance research. In: FRALEIGH, S.H.(Ed.); HANSTEIN, P.(Ed.). Researching dance: Evolving modes of inquiry. University of Pittsburgh Press, 1999.

CAMBRIDGE DICTIONARY. Cambridge University Press. Disponível em http://dictionary.cambridge.org/pt/dicionario/ingles/swing. Acesso em 13/08/2017, 22:20h.

DANTAS, M.F. Dança: o enigma do movimento. Porto Alegre: Ed. Universidade/ UFRGS, 1999.

A pesquisa em dança não deve afastar o pesquisador da experiência da dança: reflexões sobre escolhas metodológicas no âmbito da pesquisa em dança. Revista da FUNDARTE, Montenegro, v. 7, n. 13-14, 2007.

Eva Schul: uma vida para reinventar a dança moderna e contemporânea. In: SÃO PAULO. SECRETARIA DE CULTURA. Figuras da Dança: Eva Schul. São Paulo: Governo do Estado de SP, 2013.

FERNANDES, C. O corpo em movimento: o sistema Laban/Bartenieff na formação e pesquisa em artes cênicas. $2^{\underline{a}}$ ed. Annablume, 2006.

FITT, S.S. Dance Kinesiology. $2^{\text {th }}$ ed. Schirmer Cengage Learning, 1996.

RESENDE, Fellipe Santos; SILVA, Suzane Weber da. Princípios organizativos de movimento nas aulas de dança contemporânea de Eva Schul. Revista da FUNDARTE, Montenegro, p.317-338, ano 19, no 37, Janeiro/Março.

Disponível em: http://.seer.fundarte.rs.gov.br/index.php/RevistadaFundarte/index> 30 de março de 2019. 


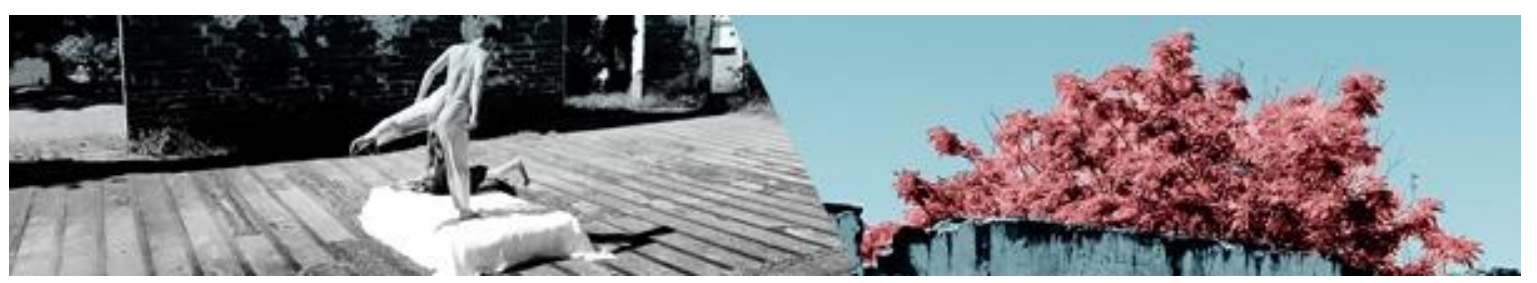

FRANCK, C. Dança Moderna: movimentos fundamentais organizados segundo os princípios da técnica de Martha Graham. Centro de Memória do Esporte da Escola de Educação Física, Fisioterapia e Dança da Universidade Federal do Rio Grande do Sul, 2013.

HAAS, J.G. Anatomia da Dança. Barueri, SP: Manole, 2012.

HACKNEY, P. Making connections: Total body integration through Bartenieff fundamentals. $5^{\text {th }}$ ed. Routledge, 2003.

HAMILTON, N.; WEIMAR, W.; LUTTGENS, K. Cinesiologia - Teoria e Prática do Movimento Humano. 12 $2^{\mathrm{a}}$ ed. Guanabara Koogan, 2013.

LABAN, R.V. Domínio do movimento. São Paulo: Summus Editorial, 1978.

LESTE, T.R. Dança: modos de estar - princípios organizativos em dança contemporânea. Dissertação (Mestrado em Dança). Universidade Federal da Bahia. Salvador, 2013.

SCHUL, E. Entrevista concedida a [Autor]. Porto Alegre/RS, 16 de Agosto de 2017.

SOARES, A.C.M. Raqs el Jaci/Dança de Jaci: hibridação por antropofagia entre a dança do ventre e a poética de Eva Schul. (Dissertação) Mestrado em Artes Cênicas. Instituto de Artes. Universidade Federal do Rio Grande do Sul, Porto Alegre, RS, 2014.

SUQUET, A. O corpo dançante: um laboratório da percepção. In: História do corpo: as mutações do olhar: o século XX. 2ª ed. Petrópolis: Vozes, 2008.

RESENDE, Fellipe Santos; SILVA, Suzane Weber da. Princípios organizativos de movimento nas aulas de dança contemporânea de Eva Schul. Revista da FUNDARTE, Montenegro, p.317-338, ano 19, no 37, Janeiro/Março.

Disponível em: http://.seer.fundarte.rs.gov.br/index.php/RevistadaFundarte/index> 30 de março de 2019. 